\title{
Economic De-integration in North America and Foreign Direct Investment from Japan
}

By

\author{
Nobuhiro Hosoe
}

May 2020

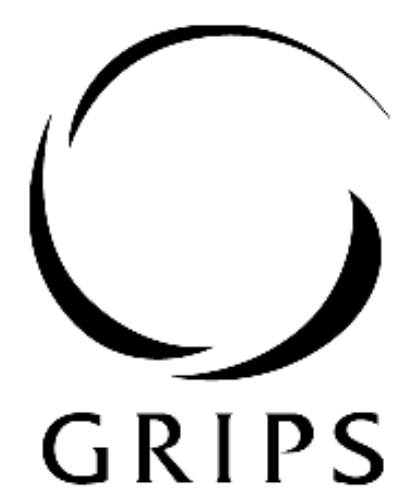

National Graduate institute FOR POLICY STUDIES

National Graduate Institute for Policy Studies

7-22-1 Roppongi, Minato-ku,

Tokyo, Japan 106-8677 


\title{
Economic De-integration in North America and Foreign Direct Investment from Japan
}

May 22, 2020

Nobuhiro Hosoe*

National Graduate Institute for Policy Studies

\begin{abstract}
We investigate the impact of US steel and aluminum tariffs, and the resumption of auto tariffs under the revised North American Free Trade Agreement, on trade in North America and foreign direct investment (FDI) from Japan, from the perspective of the auto industry. The results of policy simulation analyses with a recursive dynamic computable general equilibrium model are as follows. Canada and Mexico would benefit from US steel and aluminum tariffs, being alternative trade partners with both the US and other countries. Due to the auto tariffs on intraNorth America exports, Canada and Mexico would lose a large part of the windfall benefits from the US steel and aluminum tariffs. Japan's FDI in Canada and Mexico would fall sharply. The more de-integrated North American economies become, the more Japan would regain its auto production, although at a painful cost in terms of welfare. That negative welfare impact would be neutralized by abolition of auto tariffs with the US.
\end{abstract}

\section{Keywords}

Economic de-integration; foreign direct investment; auto industry; computable general equilibrium analysis

\section{Acknowledgements}

This study is partly supported by JSPS KAKENHI (Nos. 16H0360, 19K01622). Firm-level data in the Survey on Overseas Business Activities are provided by the Japanese Ministry of Economy, Trade and Industry. The author gratefully acknowledges these sources of support. The usual disclaimers apply.

\footnotetext{
* Author correspondence: 7-22-1 Roppongi, Minato, Tokyo 106-8677. E-mail: nhosoe@grips.ac.jp.
} 


\section{Introduction}

Since the failure of the Doha round, the move towards worldwide economic integration and the pursuit of free trade under the regime of the World Trade Organization have stagnated. Countries have shifted to alternative pathways of free trade, especially regional and bilateral free trade agreements (FTAs). Free trade negotiations, which are motivated by economy-wide benefits for each country, cannot ignore neither the political aspects of their impact on industry nor the workers left behind or negatively affected. Those negotiations, which incur high costs related to both negotiation and maintenance of free trade, have seen the above vulnerable groups suffering from impact of the recent populism movements. Member countries of mega-regional FTAs such as the European Union (EU) and the North American Free Trade Agreement (NAFTA) cannot remain unaffected by the centrifugal force pushing toward economic de-integration. Among the member countries, the US has been the leading economy in the world and has advocated free trade in principle; it has occasionally resorted to protectionist actions against Japan, such as government management of trade in sensitive goods including textiles and apparel, semiconductors, steel, and automobiles. In 2018, the US government decided to impose $25 \%$ and $10 \%$ tariffs on steel and aluminum products respectively, for the purpose of national security based on the Trade Expansion Act. The US trade disputes, which mainly targeted Japan in the 1980s, have now shifted to China, which is growing rapidly and is now the world's second largest economic power. Furthermore, the US trade conflicts are backfiring in America's backyardCanada and Mexico, the other two NAFTA members-with mutual imposition of sanctions duties.

Having experienced a series of trade disputes with the US in the 1980s, Japanese firms have made extensive foreign direct investment (FDI) in North America, including Mexico. North America attracts a quarter of Japanese FDI, although it is no longer the largest FDI destination, given the rapid growth of Asian economies, led by China (Figure 1). Japan's FDI is largely an attempt to avoid high trade barriers (including potential ones) to the entry of Japanese products to the mega-market of North America. Sales by overseas affiliates of Japanese MNEs are made 
largely by the transport equipment (auto and parts) industry, followed by chemical sector (Figure 2). While the auto sector affiliates cover about half of total Japanese affiliate sales globally and in US, the auto sector sales are dominant in Canada and Mexico, so both countries can enjoy benefits of exporting to the US without tariffs-as long as their products conform to the rules of origin (ROOs). Multinational enterprises (MNEs) invest heavily in Canada and Mexico to establish platforms there for exporting to the US (Ekholm et al., 2007). Production by Japanese auto companies in North America produce 14\%, 25\%, and 17\% of production in the US, Canada, and Mexico, respectively. ${ }^{1}$ Canada, and Mexico to an even greater degree, assemble imported parts and export finished products to the US.

\footnotetext{
1 We use Japanese auto production data from METI's Survey on Overseas Business Activities and local production data from the GTAP Database (version 10). See Hertel (1997) for GTAP Database.
} 
Figure 1: Japan's FDI [unit: billion JPY]

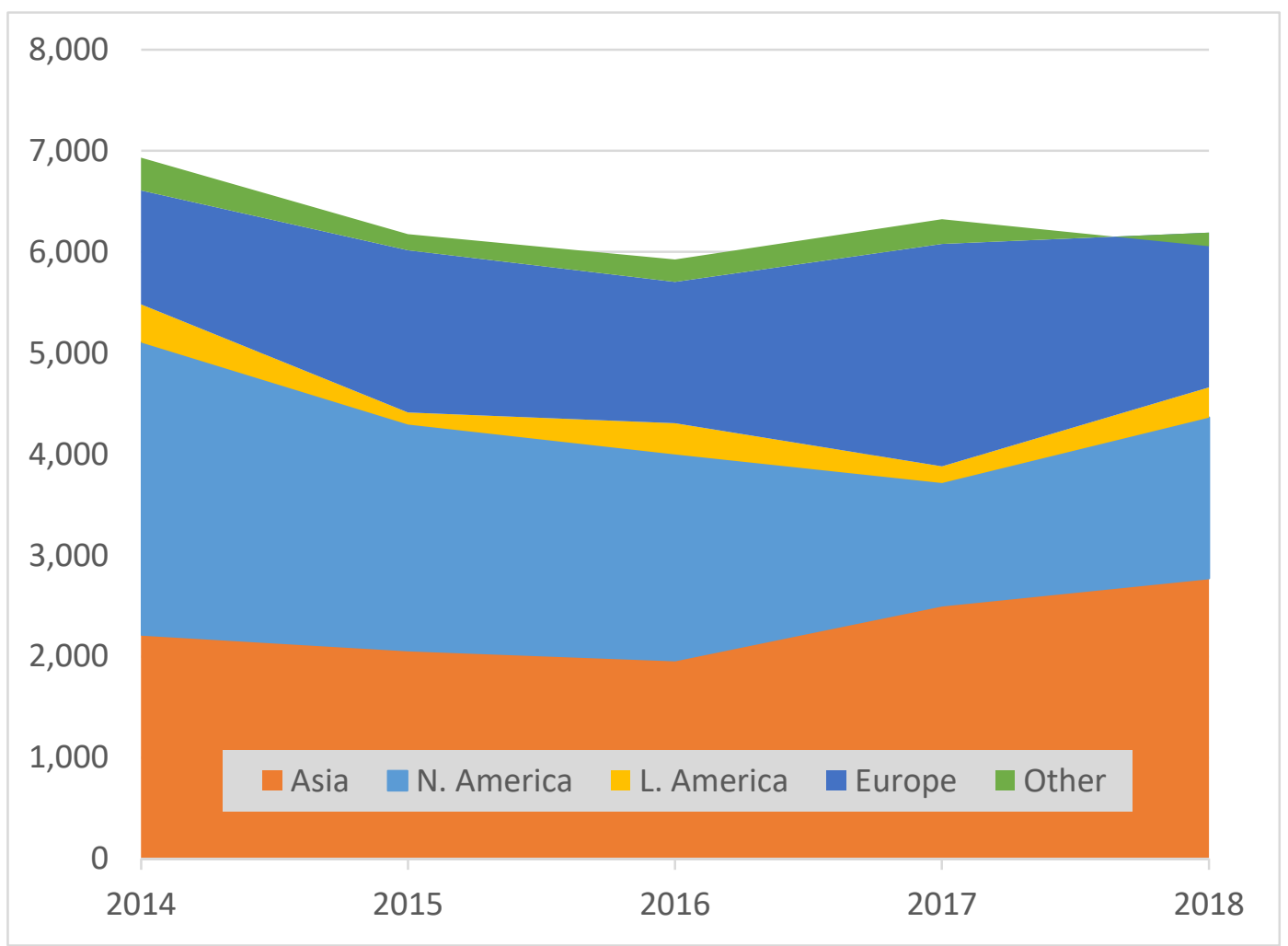

Source: Bank of Japan, Direct Investment by Region and Industry. 
Figure 2: Sales of Overseas Affiliates [unit: billion JPY]

From top left, world total, US, Canada, and Mexico

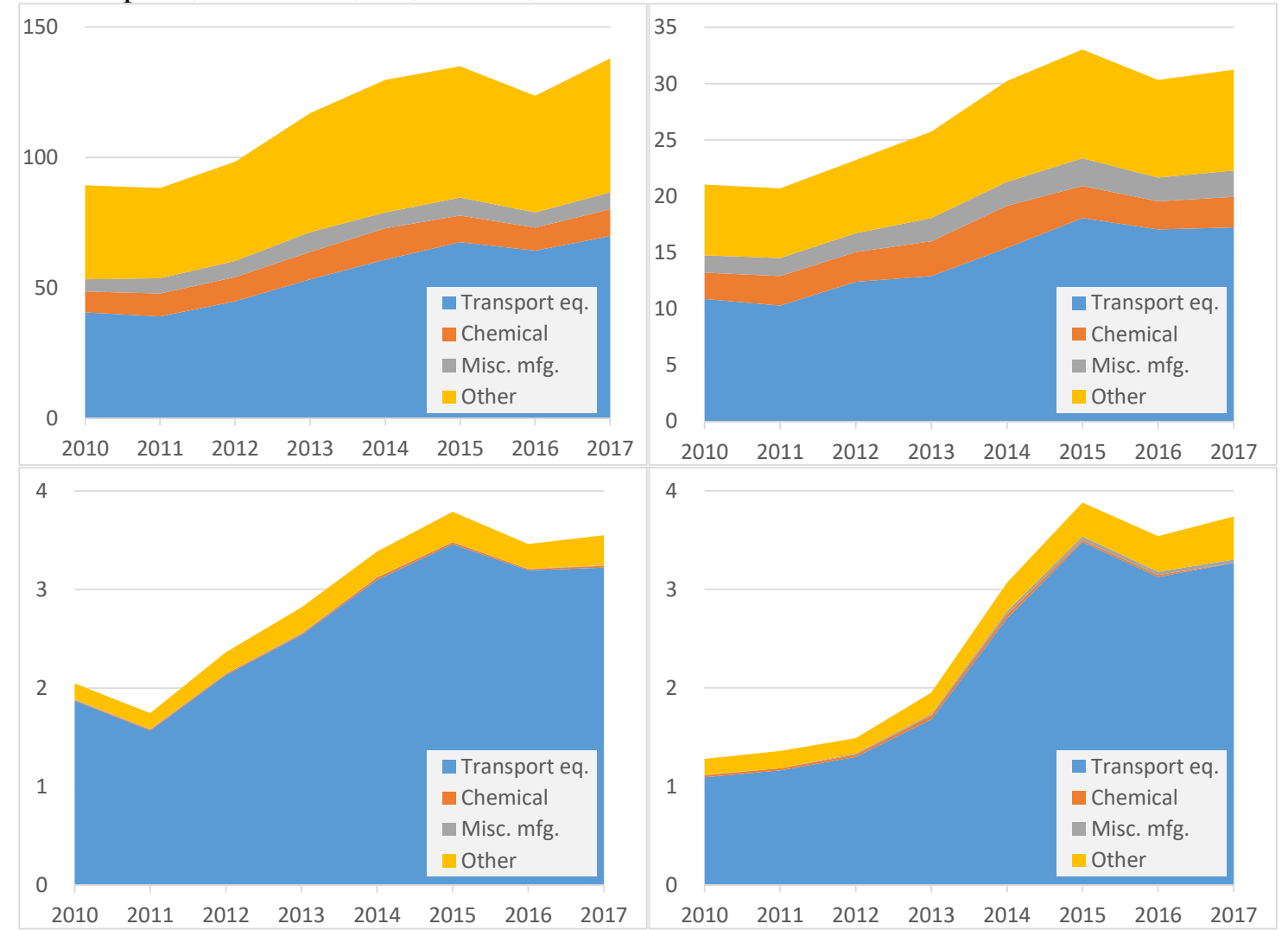

Source: Ministry of Economy, Industry and Trade (METI), Survey on Overseas Business

Activities.

Japanese MNEs have made FDIs on the assumption that the investment environment established by NAFTA would be maintained. At that time, they did not expect either the imposition of high tariffs on steel and aluminum by the US. or renegotiation of NAFTA, a.k.a. the US-Mexico-Canada Agreement (USMCA), with stricter ROOs on automobile production with higher regional value content requirements (raised from 62.5\% to 75\%), higher steel and aluminum regional value content, and a minimum wage requirement (16 USD per hour). These new requirements are very likely not possible for Canada to meet, and for Mexico even more so; 
consequently $2.5 \%$ in auto tariffs are expected to be resumed. ${ }^{2}$ These barriers affect supply chains, which span all NAFTA members. Disrupting the supply chains would make Canada and Mexico less attractive platforms for export to US markets; Japanese FDI might be redirected to the US. At the same time, the NAFTA region as a whole becomes a less attractive FDI destination, which could decelerate FDI to the US.

Many studies have conducted assessments of the impact of NAFTA, with extensive use of computable general equilibrium (CGE) models to quantify that impact (Burfisher et al., 2001; Francois \& Shiells, 1994; Kehoe \& Kehoe, 1995) and predict the manner in which NAFTA would contribution to the integration and reshaping of the three economies. For example, there is a general consensus that among the three countries, Mexico would benefit most from the NAFTA, as a result of increased trade. If the survival of NAFTA were at stake, there is concern that the NAFTA members would lose amounts as large as or even larger than their gains over the last two decades.

That concern motivated several assessments of the impact of NAFTA de-integration and the establishment of USMCA. Baier, Bergstrand and Bruno (2019), employing a structural gravity

${ }^{2}$ Uchiyama (2019) reports that, according to officials of Mexican automobile firms, passenger cars are about to be subject to a $2.5 \%$ MFN tariff, which is not so high, and perhaps affordable for them, compared with the cost of reorganizing their production processes to meet the new ROOs; and that they can manage the new ROOs for pickup trucks, which are slated to be subject to a $25 \%$ MFN tariff. Dziczek et al. (2018) reports a similar assessment of the Mexican situation. Currently, Japanese companies pay their employees high wages, i.e. three times higher than the local minimum wage (90MXN=4.8USD), but they cannot afford to pay the high USMCA minimum wage. USITC (2019) estimates that the new ROOs would increase production costs of two core components (engines and transmissions) and raise US consumer prices by $1.61 \%$ for small cars and $0.42 \%$ for mid- and full-size cars. These estimates are by and large comparable with the impact of the MFN tariff rate of $2.5 \%$. 
model to simulate a NAFTA breakdown, predict that intra-NAFTA trade volume would be halved and that Canada would experience the most serious losses in welfare (measured as real wages), followed by Mexico and the US. Lu (2018) simulates an imposition of most-favored nation (MFN) tariffs on textiles and apparel products using a CGE model based on GTAP Database (version 9). ${ }^{3}$ The simulation results of an impact assessment of US steel and aluminum tariffs by Kawasaki (2018), using a CGE model based on GTAP Database (version 10) (hereafter GTAP10) suggest that those tariffs would succeed in protecting the US metal sector but would harm users of metal products, such as the electronic equipment, machinery, and auto industries. In terms of gross domestic product (GDP), Mexico would lose most, followed by Canada and the US. Burfisher et al. (2019) and United States International Trade Comission (USITC) (2019) are the most comprehensive studies, examining the agriculture and automobile sectors and market access provisions with tariff and nontariff barriers, using GTAP10-based world trade static CGE models.

Most of the above assessments, however, do not consider either how FDI would be affected by the new barriers posed by the steel and aluminum tariffs and USMCA, or how FDI would affect those economies under the new trade regimes. Dhingra et al. (2016) point out in their analysis of the UK's withdrawal from the EU (a.k.a. Brexit) that FDI would exacerbate the (negative) impact of economic de-integration; so would it in this USMCA context. USITC (2019) is the only study in the group that considers the importance of FDI or MNEs in its USMCA analysis using a gravity model to estimate sales losses of foreign affiliates in North America. In the GTAP-FDI CGE model they use, the productivity of those affiliates is calibrated to reproduce that sales reduction in order to assess its macroeconomic implications. However, its analysis suffers two drawbacks. FDI only accompanies sales reductions by foreign affiliates, which is estimated outside the CGE model. The GTAP-FDI CGE model is a static model and thus can neither examine the evolution of FDI and other key variables over time, nor consider adjustments

\footnotetext{
${ }^{3}$ See Hertel (1997) for details of the Global Trade Analysis Project (GTAP) and its CGE model.
} 
to FDI and domestic capital stocks, which are costly to adjust and thus would be accumulated and relocated sluggishly. USITC (2019) and Burfisher et al. (2019) include Japan as part of their world trade models but do not report impacts on either the Japanese economy or FDI.

Uchiyama (2019) argues that Mexico accepted the new USMCA deals, far worse than the original ones, to avoid a complete breakdown of NAFTA, which could trigger a capital flight, especially of FDI. Indeed, the Mexican macroeconomy has relied heavily on FDI (Blecker, 2009); NAFTA has accelerated FDI inflows into Mexico (Cuevas et al., 2005; Waldkirch, 2003). By accepting FDI, regional economies have improved productivity (Waldkirch, 2010). This sheds light on the role of FDI: Mexico's losses from a resumption of auto tariffs under the USMCA could be far larger than its gains from NAFTA, which were demonstrated in earlier studies (López-de-Silanes et al., 1994; Markusen et al., 1995). In light of the above, FDI should be considered a key variable in our analysis. Aside from the abovementioned studies on FDI in Mexico, there are many earlier studies on FDI in the context of NAFTA (Globerman \& Shapiro, 1999; MacDermott, 2007). Krugman \& Hanson (1993) examine the impact of a tariff removal under NAFTA in terms of locational choice by US firms. Studies in Falck-Reyes \& GuzmanAnaya (2018) examine the roles played by Japanese auto FDI in the Mexican economy by examining the regional or firm-level impact of that FDI, but provide only a sketch of the macroeconomic aspect.

Given this background, we develop a world trade recursive dynamic CGE model which allows for international capital mobility in the form of FDI to examine the impacts of economic de-integration in North America. We examine the impact of hikes in (a) the US steel and aluminum tariffs and (b) auto tariffs between USMCA members; and of (c) hypothetical abolition of auto tariffs between the US and Japan, which was not agreed in their trade negotiations in 2019. Simulating the impact of the above trade policies, we find that while the steel and aluminum tariffs would reduce US auto production considerably, Canada and Mexico would gain from them as alternative trade partners in North America. Auto tariff resumption in the USMCA would curb 
auto production in Canada and Mexico but would not contribute to an increase in US production. North American economic de-integration would promote auto production in Japan, inflicting collateral damage on Japan's welfare-although it would be possible to recover that welfare loss by means of the auto tariff removal with the US.

This paper proceeds as follows. Section 2 presents our CGE model and the data used to construct it. Section 3 lays out the simulation scenarios. Section 4 presents the simulation results, and discusses impacts of economic de-integration in North America in terms of auto production, bilateral trade and FDI, and welfare. Section 5 presents conclusions, and indicates future extensions of the research reported here.

\section{Recursive Dynamic CGE Model}

\subsection{Within-period Static Structure}

In order to quantify impacts of trade barriers arising in North America on North American economies, world trade, and Japanese FDI, we develop a world trade recursive dynamic CGE model with multi-national enterprises (MNEs) (Hosoe, 2014). The model consists of two components. One is a static model part, which describes economic activities within a period, using nested-constant elasticity of substitution (CES)/transformation (CET) functions. The other component is a dynamic model that links periods with capital accumulation. We distinguish the three USMCA members, Japan, and six other regions (Table 1). 
Table 1: Sectors and Regions

\begin{tabular}{|c|c|}
\hline Sector & Region \\
\hline Agriculture & Japan \\
\hline Coal & US \\
\hline Petroleum & Canada \\
\hline Natural Gas & Mexico \\
\hline Food $^{*}$ & EU \\
\hline Textiles and apparel ${ }^{*}$ & Latin America \\
\hline Wood and paper products ${ }^{*}$ & Southeast Asia \\
\hline Chemicals* & South Asia \\
\hline Oil and petroleum products* & East Asia \\
\hline Ceramics* & Rest of the world \\
\hline Steel $^{*}$ & \\
\hline \multicolumn{2}{|l|}{ Nonferrous Metals* } \\
\hline \multicolumn{2}{|l|}{ Metal products* } \\
\hline \multicolumn{2}{|l|}{ Transport equipment ${ }^{*}$} \\
\hline \multicolumn{2}{|l|}{ Electronic equipment ${ }^{*}$} \\
\hline \multicolumn{2}{|l|}{ Other manufacturing ${ }^{*}$} \\
\hline \multicolumn{2}{|l|}{ Electricity } \\
\hline \multicolumn{2}{|l|}{ Town gas } \\
\hline Transportation services & \\
\hline Other services & \\
\hline
\end{tabular}

Note: * Sectors with local firms and MNEs

Each region has 20 sectors, among which 12 manufacturing sectors have two subsectors. One subsector is a local-firm sector; the other is a Japanese MNE's foreign affiliate sector. (Note that the local-firm sector can include non-Japanese MNEs' affiliates. We assume that there are no non-Japanese MNEs' affiliates operating in Japan and the rest of the world.) These two subsectors are distinguished on the basis of the nationality of their capital, which is supplied by local shareholders or Japanese shareholders in the form of FDI. Material sourcing and product sales patterns of Japanese MNEs in the 12 sectors are estimated using data from the Survey on Overseas Business Activities and GTAP10 (Figure 3); local firms souring and sales are estimated as residuals. While Japanese auto MNEs rely mostly on local input, their export sales from Mexico and Canada are mostly directed to the US, not between Mexico and Canada. 
Capital is putty-clay type capital, which once installed cannot move among sectors. Labor is skilled and unskilled; both are inter-sectorally mobile but internationally immobile. For simplicity, we assume all markets are perfectly competitive.

Figure 3: Sourcing of Manufacturing Intermediate Input (top) and Sales Destinations (bottom) by Japanese Auto MNEs Sector in North America

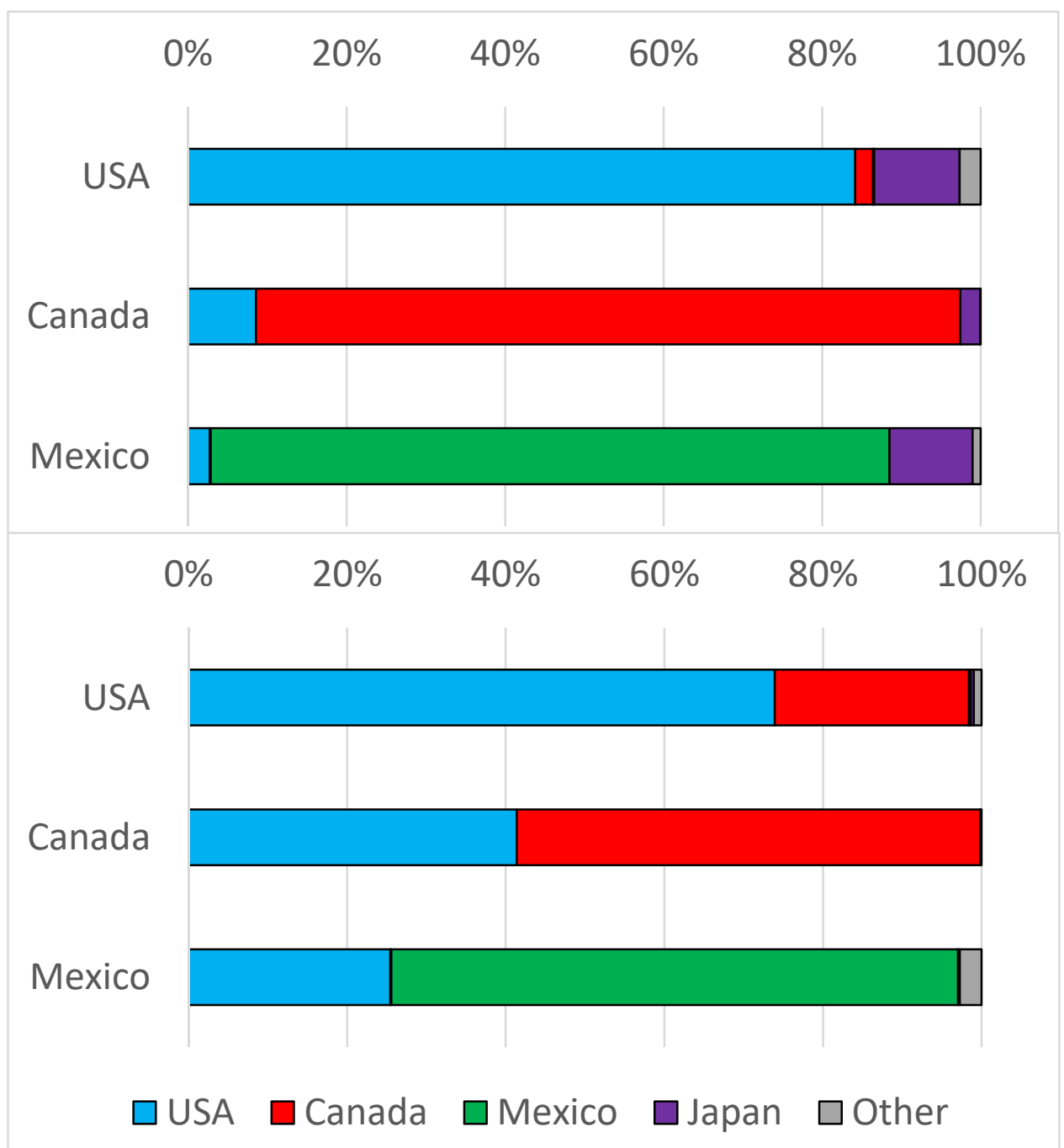

Source: Author's estimate, based on the Survey on Overseas Business Activities and GTAP10.

Products are differentiated into domestic supply and export with a CET function. The domestic good is combined with imports to produce Armington's (1969) composite good. This is 
used for household and government consumption composite capital good production for investment (discussed later), and intermediate input. For details of the static part of the CGE model, see the standard CGE model in Hosoe et al. (2010).

\subsection{Intertemporal Recursive Dynamics}

Composite capital good, which is produced with various Armington's (1969) composite goods, is allocated among sectors for investment according to expected sectoral capital service price, or rate of returns of capital, in the next period weighted with sectoral capital service input. ${ }^{4}$

4 The total investment in the $t$-th period in the $r$-th country is allocated among sectoral investment in the $i$ th sector $I I_{i, r, t}$ according to the following formula:

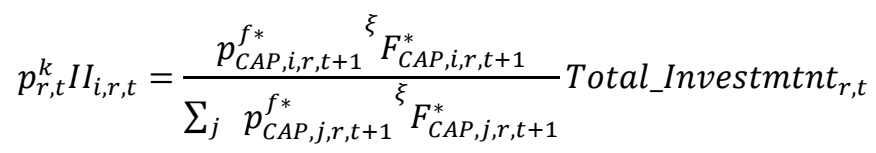

where $p_{C A P, i, r, t+1}^{f *}$ and $F_{C A P, i, r, t+1}^{*}$ are a predicted capital service price and capital service input in the $t+1$ th period. $\xi$ is an elasticity parameter that adjusts sensitivity of the allocation mechanism to differences in capital service prices among sectors. $p_{r, t}^{k}$ is a price of the investment good. Assuming myopic expectation in balanced growth, we can replace the first two variables for the $t+1$-th period with ones for the $t$-th period, augmented with a population growth rate. By doing so, we can compute the beginning-of-period capital stock in the $t+1$-th period with the equilibrium solution of the end-of-period capital stock and the sectoral investment in the $t$-th period. This generates a recursive dynamics in our model (Hosoe, 2014). Japan conducts FDI to the $i_{-} M N E$-th sector in the $s$-th region (except Japan and the rest of the world), $I I_{i_{-}} M N E, s, t$ with the following investment function with additional terms representing the capital service price, converted with an exchange rate $\epsilon_{s, r, t}$, and input by foreign affiliates.

$$
\begin{aligned}
& \epsilon_{s, r, t} p_{s, t}^{k} I I_{i \_M N E, s, t}
\end{aligned}
$$

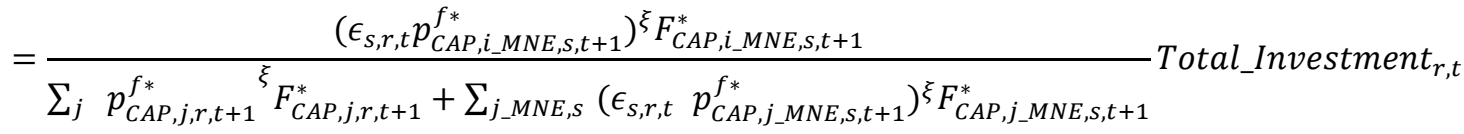


Adding this new capital to the (depreciated) end-of-period capital in the $t$-th period, we can obtain the capital stock in the $t+1$-th period. By assuming that exogenous variables, such as government consumption and capital account deficits, grow at a population growth rate, we generate a balanced growth path that serves as a business-as-usual (BAU) path in this analysis.

When we calibrate the dynamic part of the model, investment and capital stock data (reported in GTAP10) in the reference year of 2014 are not necessarily consistent with the assumed balanced growth path. Therefore, we adjust the investment data so that they generate the balanced growth path. We execute this calibration and data adjustment process, assuming the rate of returns $(5 \%)$, depreciation rate $(4 \%)$, population growth rate $(2 \%)$, and the capital allocation elasticity parameter $(\xi=1) .{ }^{5}$ For our policy simulation, we assume permanent shocks occurring in the first period and run the model for 20 years to examine the impact of those shocks on the growth paths.

The main source of data and parameters is GTAP10. We combine that database with Japanese MNEs' foreign affiliate data (production, sourcing, and sales) from the Survey on Overseas Business Activities by the Japanese Ministry of Economy, Trade and Industry so as to split the 12 manufacturing sectors into local-firm and MNE subsectors. The model is calibrated to this modified social accounting matrix. ${ }^{6}$

\section{Simulation Scenarios}

To simulate trade policy changes impacting on Japanese FDI and the auto sector, we prepare the following four scenarios in combination with four different policy shocks (Table 2).

\footnotetext{
${ }^{5}$ We conduct sensitivity analysis with alternative assumptions for these parameters. Results are robust; details are reported in the Appendix.

${ }^{6}$ See Hosoe et al. (2010, Ch.5) for outlines of the calibration method.
} 
Table 2: Scenarios and Scenario Factors

\begin{tabular}{lcccc}
\hline & \multicolumn{4}{c}{ Shocks } \\
\cline { 2 - 5 } & $\begin{array}{l}\text { US steel and } \\
\text { aluminum tariff }\end{array}$ & $\begin{array}{c}\text { Tariff on Mexican } \\
\text { auto exports to the } \\
\text { USMCA }\end{array}$ & $\begin{array}{c}\text { Tariff on Canadian } \\
\text { auto exports to the } \\
\text { USMCA }\end{array}$ & $\begin{array}{c}\text { US-Japan } \\
\text { auto tariff } \\
\text { abolition }\end{array}$ \\
\hline $\begin{array}{l}\text { Scenario 1: } \\
\begin{array}{l}\text { Steel and aluminum } \\
\text { tariff }\end{array}\end{array}$ & $\mathrm{X}$ & & & \\
$\begin{array}{l}\text { Scenario 2: } \\
\text { Mexican auto export }\end{array}$ & $\mathrm{X}$ & $\mathrm{X}$ & & \\
tariff \\
$\begin{array}{l}\text { Scenario 3: } \\
\text { Mexican and Canadian }\end{array}$ & $\mathrm{X}$ & & $\mathrm{X}$ & \\
auto export tariff & & $\mathrm{X}$ & $\mathrm{X}$ & \\
$\begin{array}{l}\text { Scenario 4: } \\
\text { US-Japan auto tariff }\end{array}$ & $\mathrm{X}$ & $\mathrm{X}$ & $\mathrm{X}$ & \\
abolition & & & & \\
\hline
\end{tabular}

- Scenario 1: Steel and Aluminum Tariff

We consider tariffs on US steel (25\%) and aluminum (10\%) imports from non-USMCA countries. In our simulation we assume a $25 \%$ tariff on steel and metal imports, and a $10 \%$ tariff on nonferrous metal imports.

- Scenarios 2 and 3: Auto tariffs on Mexican and Canadian Exports

On top of Scenario 1, we assume a 2.5\% MFN tariff on Mexican auto exports to the US and Canada (Scenario 2) and the same tariff on both Mexican and Canadian auto exports to the US (Scenario 3), reflecting a situation in which they cannot meet the new ROOs. We assume no tariff on US auto exports to these two countries.

- Scenario 4: US-Japan Auto Tariff Abolition

On top of Scenario 3, we assume auto tariff abolition between the US and Japan. This was one of the major issues in their trade negotiations in 2019, but it was left unresolved. GTAP10 
reports a $1 \%$ tariff on Japanese auto exports to the US and zero tariff on US exports to Japan. This constitutes virtually unilateral tariff abolition by the US.

In these four scenarios, we do not consider any other trade provisions. That is, we do not consider a tariff exemption for steel and aluminum. We omit auto and dairy tariff quotas for US imports from the other USMCA members. If auto companies meet the new ROOs, they can export without tariffs to the US. In our simulations, we assume that as the new ROOs are too costly to meet, auto companies can afford to pay that low tariff. In their simulations, Burfisher et al. (2019) implement regional value contents and minimum wages in the ROOs for autos as a nontariff barrier and a labor tax, respectively. ${ }^{7}$ USITC (2019) estimates increases in production costs of two core parts for 393 individual vehicle models under the new ROOs and translates the cost increases into US auto production losses using a Bertrand-Nash partial equilibrium model. In addition, the GTAP-FDI CGE model of Lakatos \& Fukui (2014) is used by USITC (2019) to estimate an import cost increase that brings the estimated production cost increases in the US, in order to estimate macro impacts of its shock.

We run the model without any shocks and obtain a balanced growth BAU path, where all variables but prices grow at the assumed population growth rate (2\%). In our policy simulations, we examine how much those variables deviate from the BAU path with the shocks listed in Table 2.

\footnotetext{
${ }^{7}$ They assume that the nontariff barrier halves NAFTA preference margins. The labor tax is set so as to increase wage costs by $50 \%$.
} 


\section{Simulation Results}

\subsection{Impacts on Auto Production}

The US steel and aluminum tariffs (Scenario 1) would contribute to the protection of the metal sectors but would harm other domestic industries, especially autos, that use those metal products (Figure 4). US auto production would be reduced by $9-13$ billion USD (about $1.0 \%$ of the BAU production level) and would continue to decline. To fill that supply gap, Japan and other regions would accelerate production. Canada and Mexico, which are not affected directly by the steel and aluminum tariffs, could become alternative production bases for exporting to the US. However, due to the tightness of supply chains involving the US, the decline of US auto production is propagated negatively to the other two USMCA members, leading to a slight decline in their production.

Figure 4: Production of Transport Equipment [Deviations from the BAU Path, billion USD]

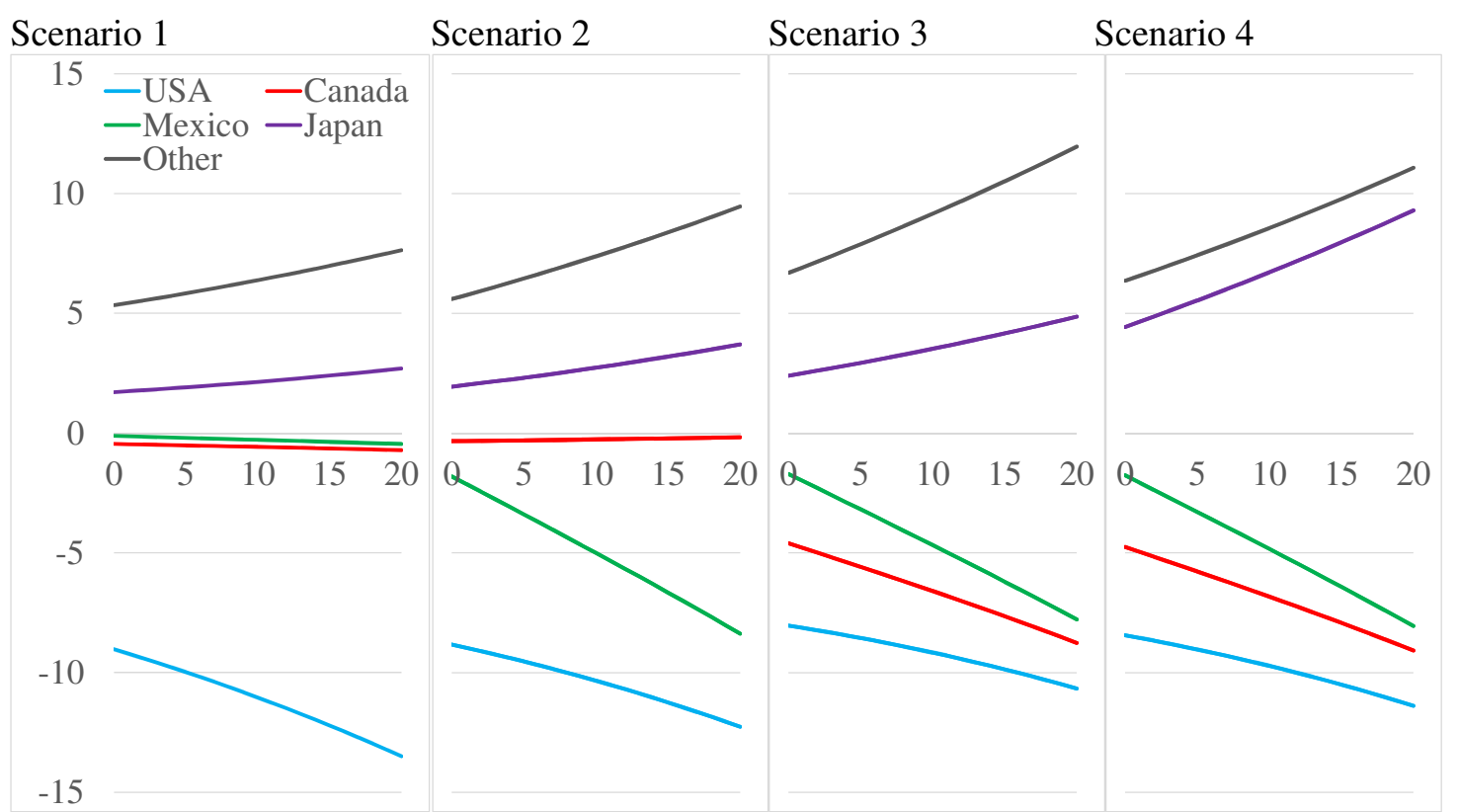

Note: Total current value of auto production by local firms and MNEs, combined with Laspeyres price index. "Other" represents the total of the other six regions. 
If auto tariffs are resumed on top of the US steel and aluminum tariffs (Scenario 2), Mexican auto production would decline by $1.5 \%$ initially but more severely, by $4.5 \%$, in the long run. The decline of Mexican auto production provides more room for non-USMCA auto producers to grow and for the US to recover slightly from the negative impact of its steel and aluminum tariffs, demonstrated in Scenario 1. Canada would be able to recover its production to the BAU level in the long run.

However, this windfall effect on Canadian production would be completely overshadowed by the negative impact of auto tariffs on Canadian (and Mexican) exports, though it could be as low as $2.5 \%$ (Scenario 3). While initially Canada's loss (5.3\% of the BAU level) would exceed Mexico's, their losses would converge in the long run. The lost production by Canada would be covered by non-USMCA members.' Japan would gain in production by $0.5-$ $0.6 \%$, compared with the BAU level.

Japanese auto exports to the US are subject to a tariff, though it could be as low as $1 \%$. Its abolition (Scenario 4) would double the gains in Japan's production. This additional gain is attributable solely to an increase in exports to the US. The other region's production, targeted at exporting to the US, would be reduced accordingly.

\subsection{Impacts on Bilateral Trade}

Figure 5 shows changes in bilateral trade among Japan and the three USMCA members. The steel and aluminum tariffs would reduce imports from Japan; their hike in material input costs in the US harms its domestic production and its exports. In contrast, Mexico and Canada do not impose steel and aluminum tariffs and thus do not suffer input cost hikes. Moreover, as they benefit from the same tariff-free access to the US market, Mexican and Canadian exports to the US would increase sharply. In terms of magnitude, Canada's gain would be twice that of Mexico. Japan would shift the destination of its exports from the US to the other two members, so to avoid high US tariffs and to export indirectly to the US, exploiting the advantage of trade with the other 
two USMCA members.

Figure 5: Bilateral Trade [deviations from the BAU path, billion USD]

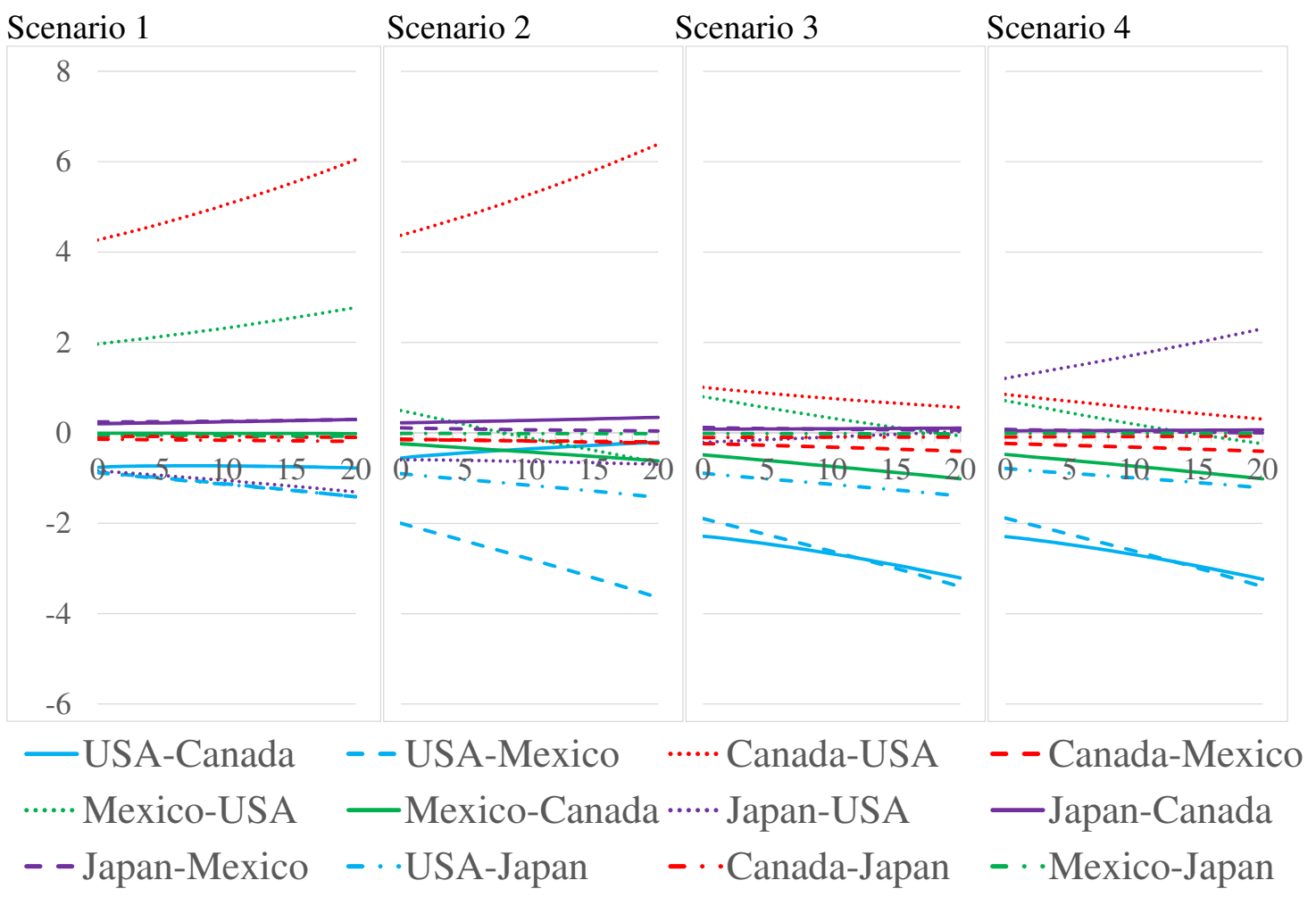

In Scenario 2, with a 2.5\% tariff on Mexican auto exports to the US and Canada, Mexican exports to the US would increase in the short run, when the windfall benefits from the US steel and aluminum tariffs would be significant, but would undercut the BAU level in the long run. US exports to Mexico would be harmed further. By contrast, bilateral trade between the US and Canada would slightly increase. Japanese exports to Mexico and Canada, being affected by the fall and rise of these two economies, respectively, would be maintained still slightly above their BAU levels. If Canadian auto exports were also tariffed (Scenario 3), trade between Canada and the US would be significantly reduced. However, the advantage of the Canadian economy as an export base to the US allows Canada to maintain its exports still above the BAU level.

While impacting little on other bilateral trade flows, the abolition of US-Japan auto tariffs (Scenario 4) would increase Japanese exports to the US by $0.9-1.1 \%$. Accompanying this 
increase, exports from other regions, especially from major EU and East Asia auto producers, would reduce exports to the US (not shown in Figure 5).

\subsection{Impacts on Japanese FDI}

Figure 6 shows the expected impacts on Japanese FDI. The US tariffs on steel and aluminum (Scenario 1) make the production of other goods disadvantageous and reduce returns from capital installed in the US. On the one hand, this attracts less FDI to the US. Investment would exit the US presumably to the other two USMCA members, which are still accessible to the US markets. On the other hand, Canada and Mexico are tightly linked with the US through their supply chains, and thus would experience collateral damage from the contraction of US auto production. These two forces work in opposition; the total impact on Japanese FDI to Mexico and Canada would be more or less neutral. Japanese investment would be redirected, partly to the domestic sectors and partly to other regions, both of which are less affected by the US tariffs.

Figure 6: Japanese FDI in the Transport Equipment Sector [deviations from the BAU path, billion USD]

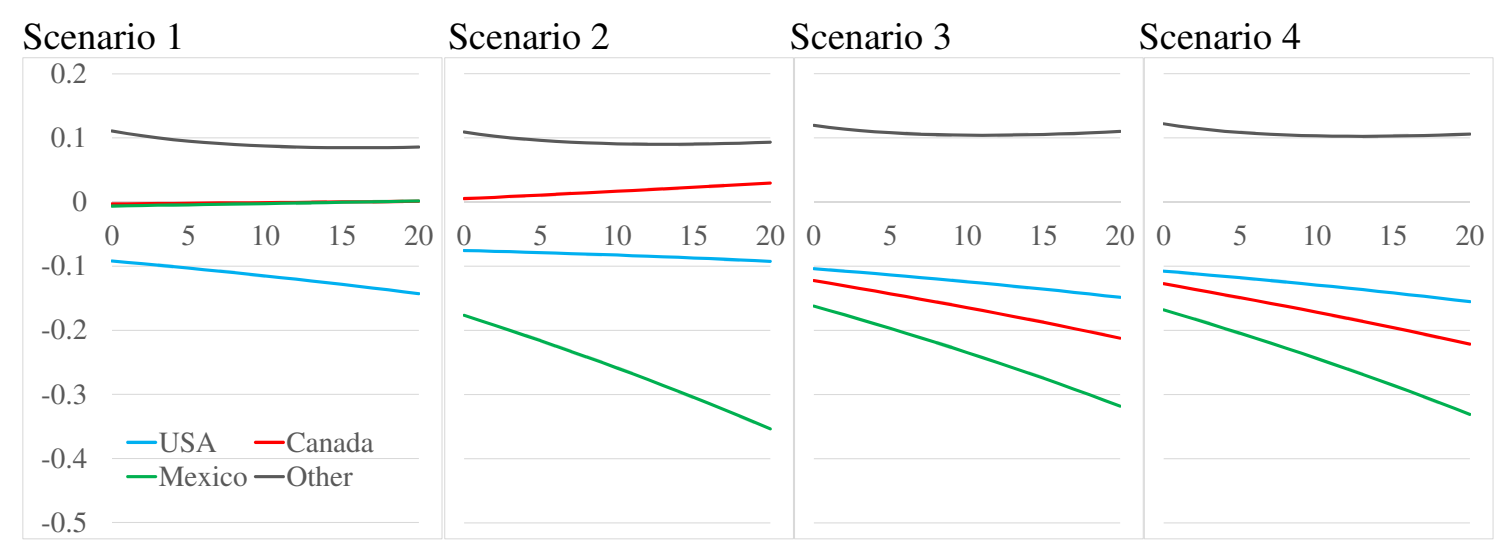

The $2.5 \%$ auto tariff, which makes Mexico less attractive as an export platform, would impact Mexico's FDI inflow severely (Scenario 2). In contrast, the US and Canada, whose exports 
are not subject to the auto tariff, would become more attractive destinations for Japanese FDI. Canada in particular would become an alternative export platform to US markets and would experience a steady increase in FDI inflows. The US would also regain its attractiveness, albeit gradually; in the long run its FDI inflow would return to the BAU level. Given such an outcome, the USMCA renegotiation over the auto industry would emerge as successful for the US.

If Canada were also subject to the auto tariffs (Scenario 3), it would completely lose its advantageous role as an export platform. Like Mexico, it would lose FDI. Canada's FDI loss would eventually grow half as large as Mexico's. Once the US lost both partners, Mexico and Canada, could the US be expected to resume its leading role in the auto industry in North America? That could not happen. Breaking away from those two partners would fracture the supply chains that have been developed across North America in the last quarter century, which would in turn reduce the profitability of FDI to the US, and FDI inflows would decrease.

Abolition of US-Japan auto tariffs (Scenario 4) would significantly affect Japan's auto production (Figure 4) and its exports to the US (Figure 5), but would affect FDI only a little. Increases in domestic production and exports of finished products to the US are expected to reduce (horizontal) FDI to the US. In contrast, as parts exports would also be bolstered by the zero auto tariff, more (vertical) FDI would be needed to accelerate assembly in North America. Between exports and FDI, there are substitutive and complementary relationships working in tandem and in opposition in modern networked FDI (Baldwin \& Okubo, 2014). Therefore, it appears that the total impact would be more or less neutral.

\subsection{Impacts on Welfare}

The US would gain slightly (10-13 billion USD) from the steel and aluminum tariffs (Scenario 1) (Figure 7). Canada and Mexico would enjoy windfall gains twice as large as those of the US, normalized by their GDP. Canada and Mexico's gains would originate from a trade diversion effect, which would shift export destinations from the US to Canada and Mexico as a 
result of the steel and aluminum tariffs (Figure 5). This trade diversion would encompass two scenarios: a shift of final export destinations; and a de facto by-pass of exports to the US, with some processing in the two countries. Both cases would be beneficial for Canada and Mexico.

Figure 7: Welfare Impacts Measured in Equivalent Variations [\% of BAU GDP]

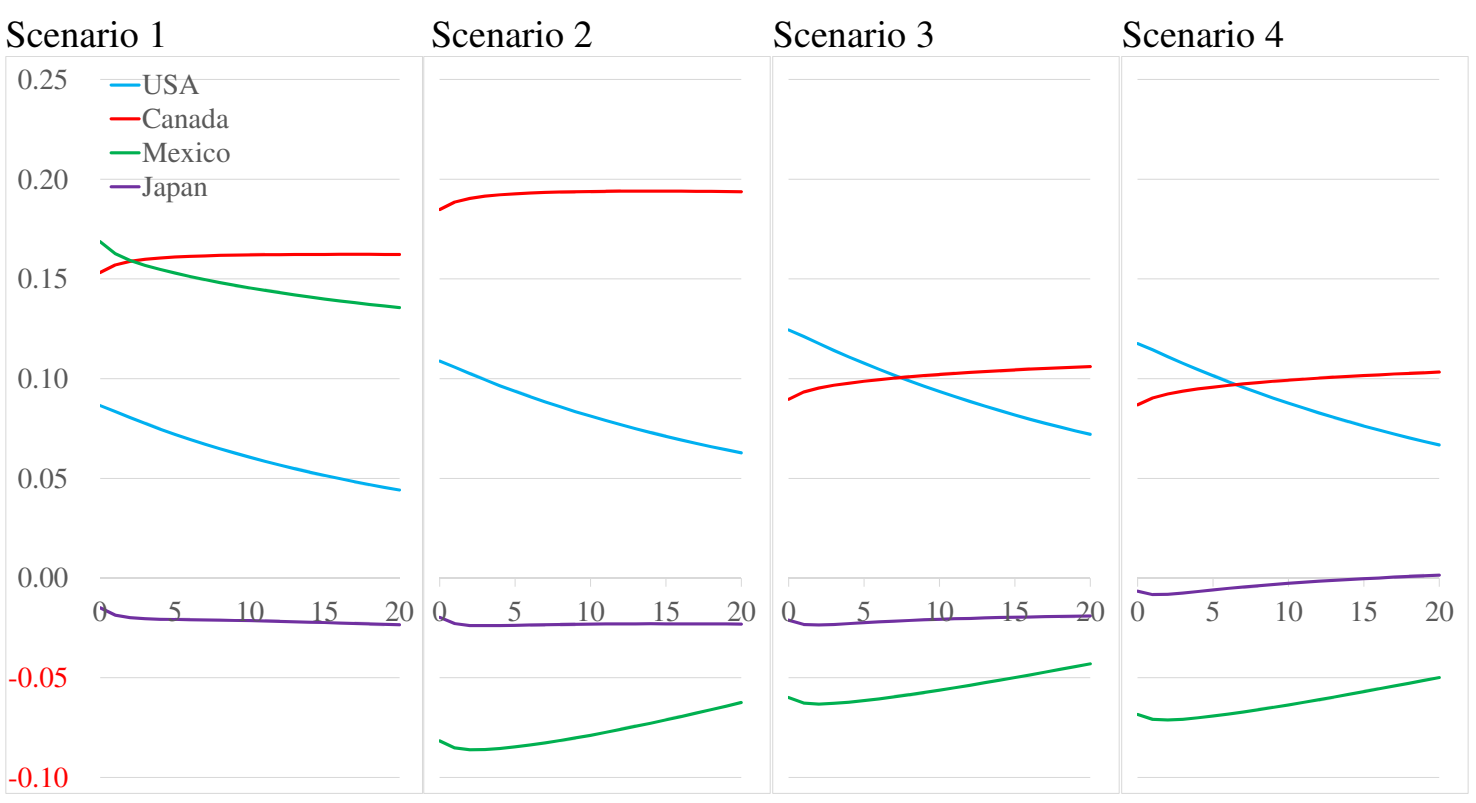

Facing an auto tariff (Scenario 2), Mexico would lose the benefit of its USMCA membership; part of that benefit would be captured by Canada. If Canada also faced an auto tariff (Scenario 3), the gains captured by Canada would be halved. However, the windfall benefit from the US steel and aluminum tariffs would be immense for Canada, because Canada's metal exports to the US are double those of Mexico. ${ }^{8}$ Canada would not experience as sharp an FDI flight as Mexico. Therefore, Canada would be still better off than the status quo.

Economic de-integration measures in North America would pose an obstacle to Japanese exports to the US and would reduce returns from Japan's FDI in Canada and Mexico-

\footnotetext{
${ }^{8}$ GTAP10 reports 302 billion USD in exports of steel, nonferrous metal, and metal products from Canada to the US, and 159 billion USD in such exports from Mexico to the US.
} 
all of which would negatively impact Japan's welfare. The abolition of US-Japan auto tariffs (Scenario 4) could neutralize the negative welfare impacts of those tariffs in the long run.

\section{Conclusion}

We investigate the impact of economic de-integration in North America via a recursive dynamic CGE model. To encompass FDI by Japanese MNEs in the model, we distinguish between local firm sectors and Japanese MNE sectors, so as to enable description of substitution and complementarity between trade and FDI. Our analysis focuses on trade policies related to the auto industry, the target of a large share of Japanese FDI flowing into North America. In our numerical analysis, we consider US steel and aluminum tariffs, auto tariffs on Canadian and Mexican exports due to stricter ROOs, and abolition of auto tariffs between the US and Japan. The steel and aluminum tariff would severely hit the US auto industry through its material cost hike, while benefiting those protected sectors. That negative impact would be substantial. Protection at Canadian and Mexican borders by means of auto tariffs would not be sufficient for recovery of the US domestic auto production level. Since the establishment of NAFTA, supply chains have been developed across North America, and intra-industry trade in parts and finished autos has been promoted extensively. While tariffs could allow domestic auto producers to bar foreign producers from access to their domestic finished-vehicle customers, they might obstruct (imported) material supply and thus impact domestic production. Inflicting mutual damage via border protection in North America would merely create a supply gap, which could be exploited by players outside North America. In terms of welfare, the impact on Mexico would be more severe than that on Canada. This finding is consistent with the findings of the majority of earlier studies about the gains from NAFTA, although it does contrast with those of Baier, Bergstrand and Bruno (2019).

Japan would experience collateral damage from North American economic deintegration. While its domestic auto output and export volumes would grow to replace North 
American production, Japan would suffer a negative welfare impact resulting from the decline in production by its foreign affiliates in North America. FDI to Canada and Mexico America is found here to be sensitive to tariff measures. Tariff hikes on Canadian and Mexican exports to the US would provide a stronger incentive to jump tariffs by investing in the US, rather than in Canada and Mexico. However, at the same time, such hikes would undermine the benefit of the supply chains developed over North America, making North America a less attractive FDI destination. Therefore, Japanese investment would be directed to regions other than North America or stay in Japan.

We use data for Japanese MNEs' foreign affiliates in our simulation study, but we do not consider MNEs based in other countries. In the auto industry, major players have developed production bases in North America. US auto producers have invested heavily in Canada and Mexico. If we include FDI in the scenario, we can expect the impact of economic de-integration to be far larger. In this sense, our study provides a lower bound estimate of the negative impact of economic de-integration in North America. 


\section{References}

Armington, P. S. (1969). A Theory of Demand for Products Distinguished by Place of Production. IMF Staff Papers. https://doi.org/10.2307/3866403

Baier, S. L., Bergstrand, J. H., \& Bruno, J. P. (2019). Putting Canada in the penalty box: Trade and welfare effects of eliminating North American Free Trade Agreement. World Economy, 42, 3488-3514. https://doi.org/10.1111/twec.12870

Baldwin, R., \& Okubo, T. (2014). Networked FDI: Sales and sourcing patterns of Japanese foreign affiliates. World Economy. https://doi.org/10.1111/twec.12116

Blecker, R. A. (2009). External Shocks, Structural Change, and Economic Growth in Mexico, 1979-2007. World Development, 37, 1274-1284. https://doi.org/10.1016/j.worlddev.2008.10.004

Burfisher, M. E., Lambert, F., \& Matheson, T. (2019). NAFTA to USMCA: What is Gained? IMF Working Papers. https://doi.org/10.5089/9781498303286.001

Burfisher, M. E., Robinson, S., \& Thierfelder, K. (2001). The impact of NAFTA on the United States. Journal of Economic Perspectives, 15, 125-144. https://doi.org/10.1257/jep.15.1.125

Cuevas, A., Messmacher, M., \& Werner, A. (2005). Foreign direct investment in Mexico since the approval of NAFTA. World Bank Economic Review, 19, 473-488. https://doi.org/10.1093/wber/lhi015

Dhingra, S., Ottaviano, G., Sampson, T., \& Reenen, J. Van. (2016). The impact of Brexit on foreign investment in the UK. CEP BREXIT ANALYSIS, No. 3.

Dziczek, K., Schultz, M., Swiecki, B., \& Chen, Y. (2018). NAFTA Briefing: Review of current NAFTA proposals and potential impacts on the North American automotive industry. https://www.cargroup.org/wpcontent/uploads/2018/04/nafta_briefing_april_2018_public_version-final.pdf

Ekholm, K., Forslid, R., \& Markusen, J. R. (2007). Export-platform foreign direct investment. 
Journal of the European Economic Association, 5, 776-795.

https://doi.org/10.1162/JEEA.2007.5.4.776

Falck-Reyes, M., \& Guzman-Anaya, L. (Eds.). (2018). Japanese Direct Investment in Mexico's Transport Equipment Sector: Macro Impact and Local Responses. Springer.

Francois, J. F., \& Shiells, C. R. (1994). Modeling trade policy: applied general equilibrium assessments of North American free trade. Cambridge University Press.

Globerman, S., \& Shapiro, D. M. (1999). The impact of government policies on foreign direct investment: The Canadian experience. Journal of International Business Studies, 30, 513532. https://doi.org/10.1057/palgrave.jibs.8490081

Hertel, T. W. (1997). Global Trade Analysis: Modeling and Applications Cambridge University Press.

Hosoe, N. (2014). Japanese manufacturing facing post-Fukushima power crisis: a dynamic computable general equilibrium analysis with foreign direct investment. Applied Economics, 46. https://doi.org/10.1080/00036846.2014.892198

Hosoe, N., Gasawa, K., \& Hashimoto, H. (2010). Textbook of Computable General Equilibrium Modelling: Programming and Simulations. Palgrave Macmillan. https://doi.org/10.1017/CBO9781107415324.004

Kawasaki, K. (2018). Economic Impact of Tariff Hikes -A CGE model analysis-. GRIPS Discussion Papers, Article 18-05. https://doi.org/10.24545/00001619

Kehoe, P. J., \& Kehoe, T. J. (1995). Modeling North American Economic Integration. Kluwer Academic Publishers. https://doi.org/10.1007/978-94-009-0123-0

Krugman, P., \& Hanson, G. (1993). Mexico-U.S. free trade and the location of production. In P. M. Garber (Ed.), The Mexico-U.S. Free Trade Agreement (pp. 163-186). MIT Press.

Lakatos, C., \& Fukui, T. (2014). The Liberalization of Retail Services in India. World Development. https://doi.org/10.1016/j.worlddev.2014.01.013

López-de-Silanes, F., Markusen, J. R., \& Rutherford, T. F. (1994). The auto industry and the 
North American Free Trade Agreement. In J. F. Francois \& C. R. Shiells (Eds.), Modeling Trade Policy (pp. 223-255). Cambridge University Press.

Lu, S. (2018). What Will Happen to the US Textile and Apparel Industry if the NAFTA Goes? Margin: The Journal of Applied Economic Research, 12(2), 113-137. https://doi.org/10.1177/0973801018754624

MacDermott, R. (2007). Regional trade agreement and foreign direct investment. North American Journal of Economics and Finance. https://doi.org/10.1016/j.najef.2006.09.004 Markusen, J. R., Rutherford, T. R., \& Hunter, L. (1995). North American Free Trade and the Production of Finished Automobiles. In P. J. Kehoe \& T. J. Kehoe (Eds.), Modeling North American Economic Integration (pp. 117-130). https://doi.org/10.1007/978-94-009-0123$0 \_6$

Uchiyama, N. (2019). NAFTA Renegotiation and Its Impacts on Mexican Automobile Industry: The Case of Japanese Automobile Companies. LATIN AMERICA REPORT, 35, 55-69. United States International Trade Comission (USITC). (2019). U.S.-Mexico-Canada TradeAgreement: Likely Impacton the U.S. Economy andon Specific Industry Sectors. Investigation Number: TPA 105-003.

Waldkirch, A. (2003). The "new regionalism" and foreign direct investment: The case of Mexico. Journal of International Trade and Economic Development, 12(2), 151-184. https://doi.org/10.1080/0963819032000084313

Waldkirch, A. (2010). The Effects of Foreign Direct Investment in Mexico since NAFTA. World Economy, 35, 710-745. https://doi.org/10.1111/j.1467-9701.2009.01244.x 


\section{Appendix for: Economic De-integration in North America and Foreign Direct Investment from Japan}

May 15, 2020

Nobuhiro Hosoe

National Graduate Institute for Policy Studies

nhosoe@ grips.ac.jp

\section{Appendix Sensitivity Analysis}

To examine the robustness of our simulation results, shown in the main text, we conduct sensitivity analysis with alternative assumptions for six selected key parameters (Table A.1). When we assume a larger value for Armington's (1969) elasticity of substitution ( $\left.\sigma^{A R M}\right)$, impacts of tariff changes on trade are generally larger. Larger trade volume changes lead to larger changes in production and FDI. However, welfare impacts are not necessarily larger or smaller under this alternative elasticity assumption. Welfare impacts are found larger for Canada and Mexico but smaller for the US. This is because the US steel and aluminum tariff (Scenario 1) would US curb trade more under this larger elasticity assumption. On the one hand, this allows the US to capture smaller rents from other countries by tariffs. On the other hand, the larger trade volume reaction would bring a larger trade diversion effect, which would benefit Canada and Mexico. The larger elasticity would also augment those country's losses resulting from the auto tariff imposition (Scenarios 2 and 3). As the original welfare impacts for Japan are not sizable, the changes resulting from this alternative elasticity assumption are not visible. This alternative elasticity assumption alters results quantitatively but does not qualitatively. 
Table A.1: Assumed Parameters in the Main Text and Alternative Assumptions for Sensitivity Analysis

\begin{tabular}{lcc}
\hline & $\begin{array}{c}\text { Assumed values in the } \\
\text { main text }\end{array}$ & $\begin{array}{c}\text { Alternative } \\
\text { assumption }\end{array}$ \\
\hline Armington's $\quad(1969) \quad$ elasticity $\quad$ of & $\begin{array}{c}1.90-17.2 \\
\text { (GTAP 10) }\end{array}$ & $+30 \%$ \\
substitution: $\sigma^{A R M}$ & $0.20-1.68$ & $+30 \%$ \\
Elasticity of substitution among primary & $($ GTAP 10) & \\
factor input: $\sigma^{V A}$ & $4 \%$ & $5 \%$ \\
Depreciation rate: $\delta$ & $5 \%$ & $6 \%$ \\
$\begin{array}{l}\text { Rate of returns: } r o r \\
\text { Population growth rate: } p o p\end{array}$ & $2 \%$ & $3 \%$ \\
$\begin{array}{l}\text { Elasticity parameter of sectoral investment } \\
\text { allocation function: } \zeta\end{array}$ & 1 & 2 \\
\hline
\end{tabular}

Larger elasticity of substitution among primary factor input of capital and skilled and unskilled labor $\left(\sigma^{V A}\right)$ allows economies to adjust their domestic industrial production to shocks by means of more flexible reallocation of resources. Therefore, the impacts on production are found larger (Figure A.2). However, the quantitative changes resulting from this alternative elasticity assumption are small, and there are no qualitative changes in results. Trying alternative values for the depreciation rate $(\delta)$ and the rate of returns (ror) used for calibration, we find only small quantitative differences and thus no qualitative differences in results (Figure A.3 and Figure A.4). Assuming a higher population growth rate (pop), the economy would be expected to grow faster in the BAU and counterfactual paths. Due to this effect alone, changes shown in level values appear larger (Figure A.5). However, when we normalize the impact by the BAU GDPs, results are little affected, as shown in welfare impacts. When the elasticity parameter in the sectoral investment allocation function $(\zeta)$ is doubled, investment allocation becomes more sensitive to the gap among capital service prices (or rates of returns of capital) of sectors (Figure A.6). As can be seen in the figure reporting FDI changes, investment is more quickly adjusted after a shock. For example, in Scenarios 3-4, Mexico, which heavily relies on FDI, shows a deeper cut in its auto production than Canada. Quicker adjustment reduces deviations from the BAU path in the long run. 
Figure A.1: $30 \%$ Larger Armington Elasticity $\left(\sigma^{A R M}\right)$

Production of Transport Equipment [Deviations from the BAU Path, billion USD]

Scenario1

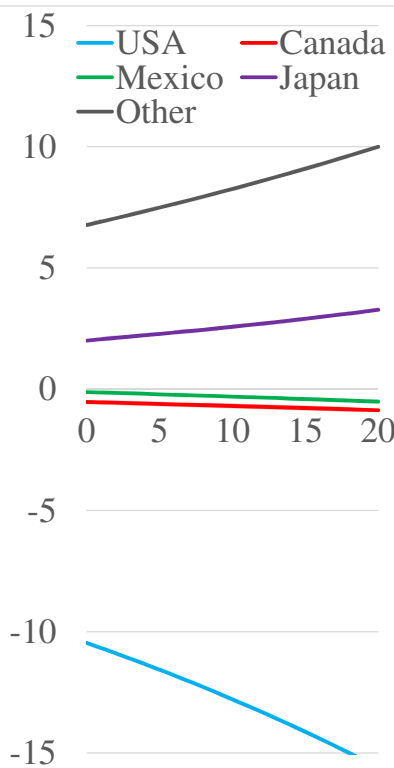

Scenario2

.
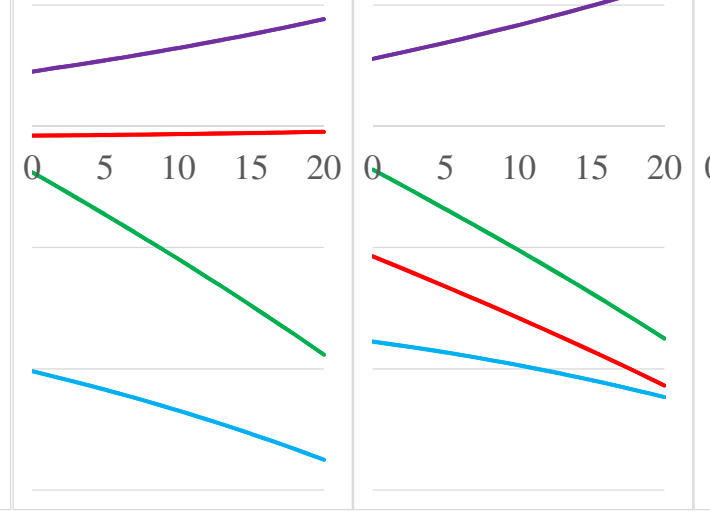

Bilateral Trade [Deviations from the BAU path, billion USD]

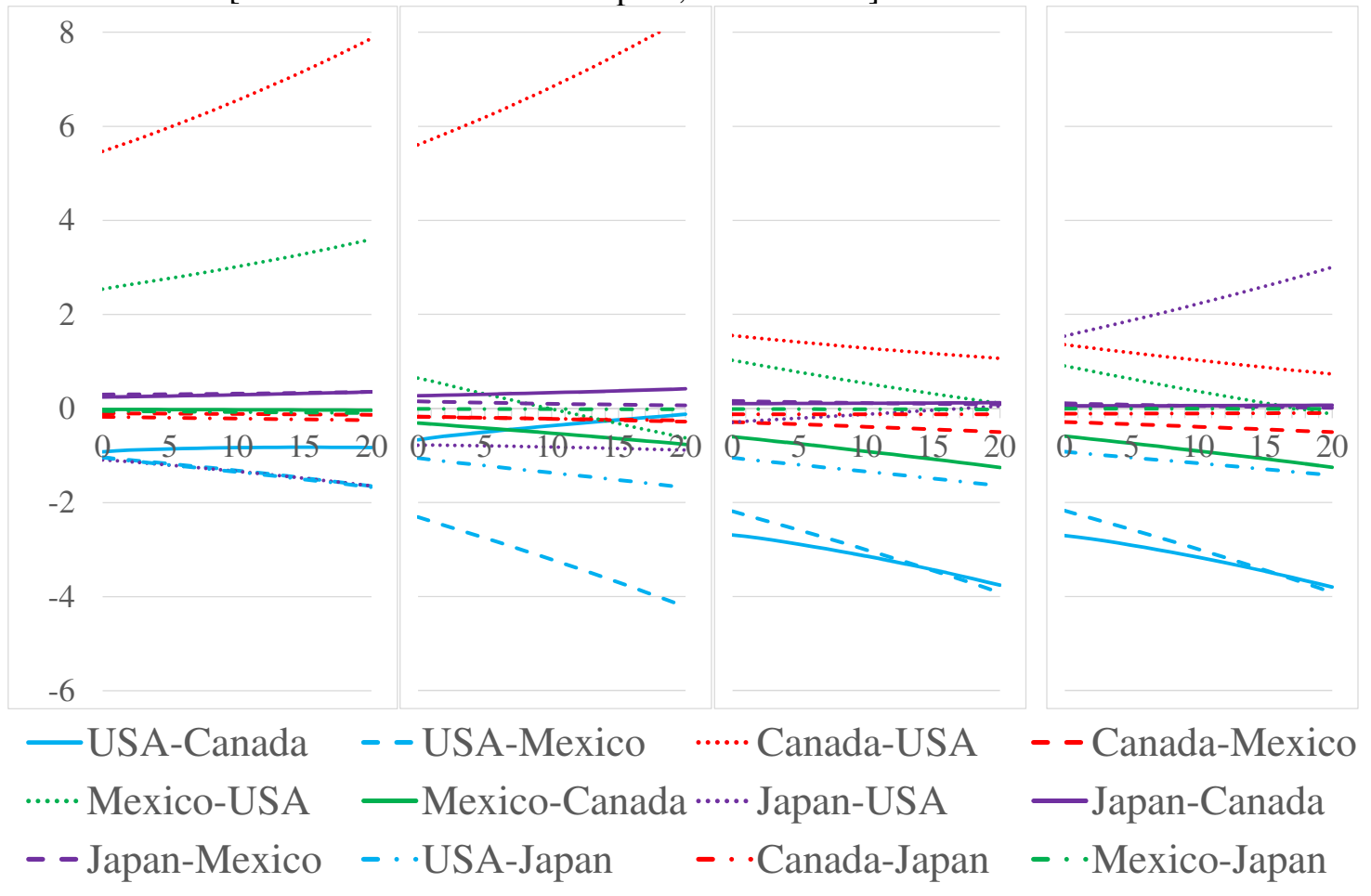


Japanese FDI in the Transport Equipment Sector [Deviations from the BAU path, billion USD]
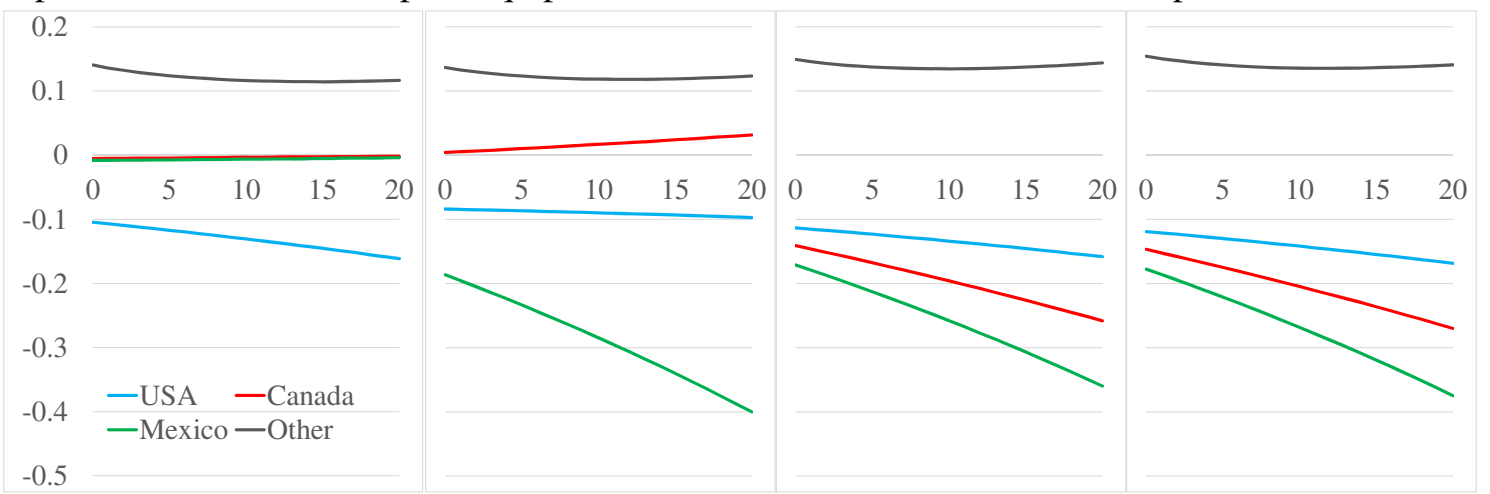

Welfare Impacts in Equivalent Variations [\% of BAU GDP]

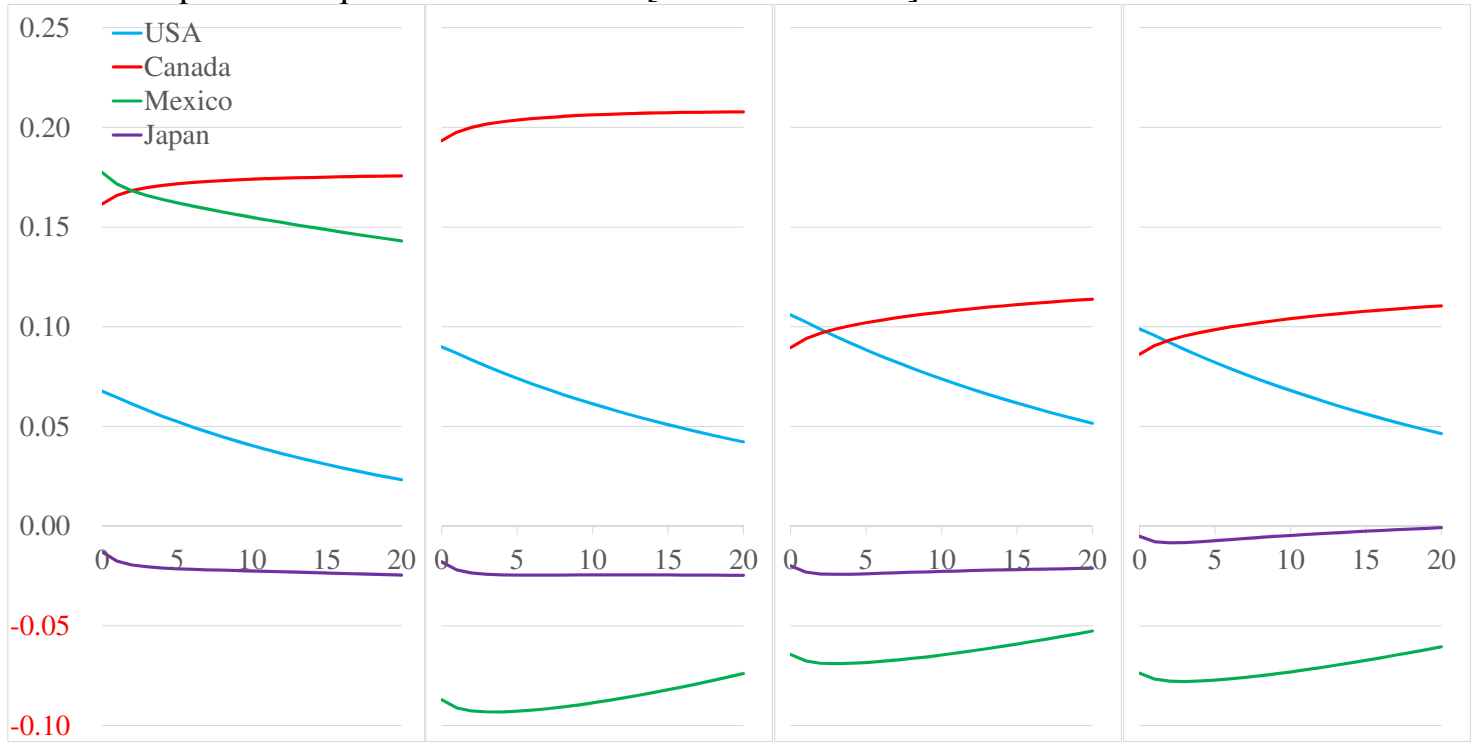


Figure A.2: 30\% Larger Elasticity of Substitution among Primary Factor Input $\left(\sigma^{V A}\right)$ Production of Transport Equipment [Deviations from the BAU Path, billion USD]

Scenario1

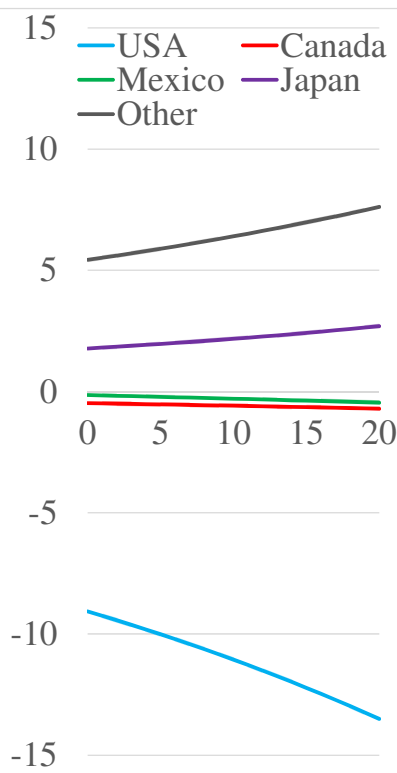

Scenario2

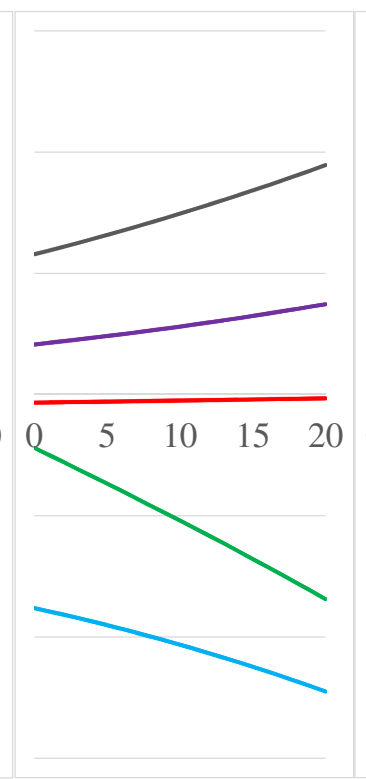

Scenario3

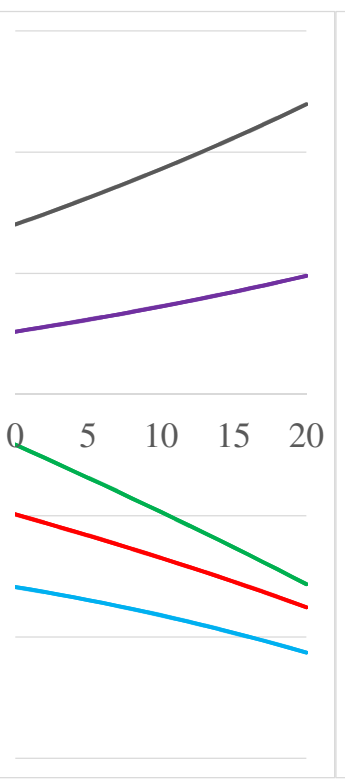

Scenario4

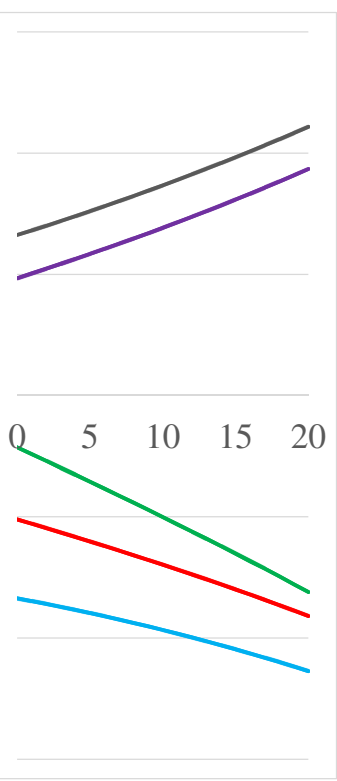

Bilateral Trade [Deviations from the BAU path, billion USD]

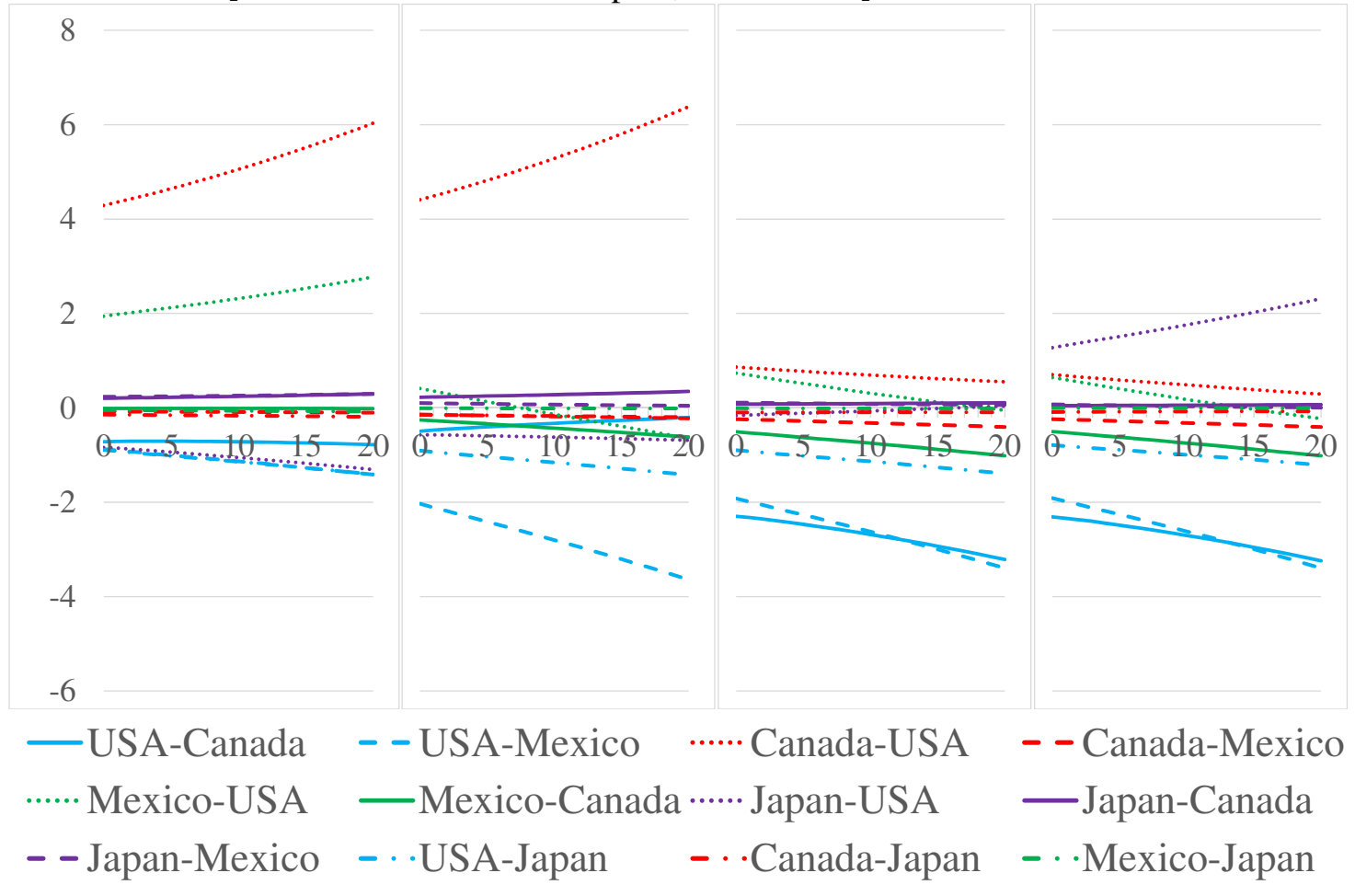


Japanese FDI in the Transport Equipment Sector [Deviations from the BAU path, billion USD]

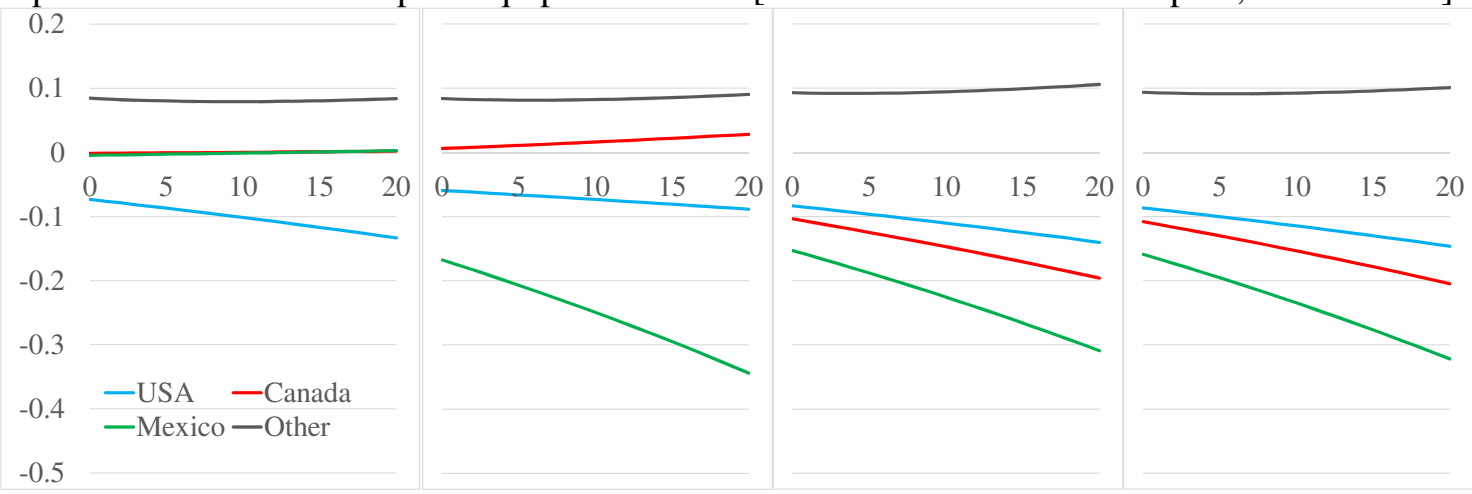

Welfare Impacts in Equivalent Variations [\% of BAU GDP]

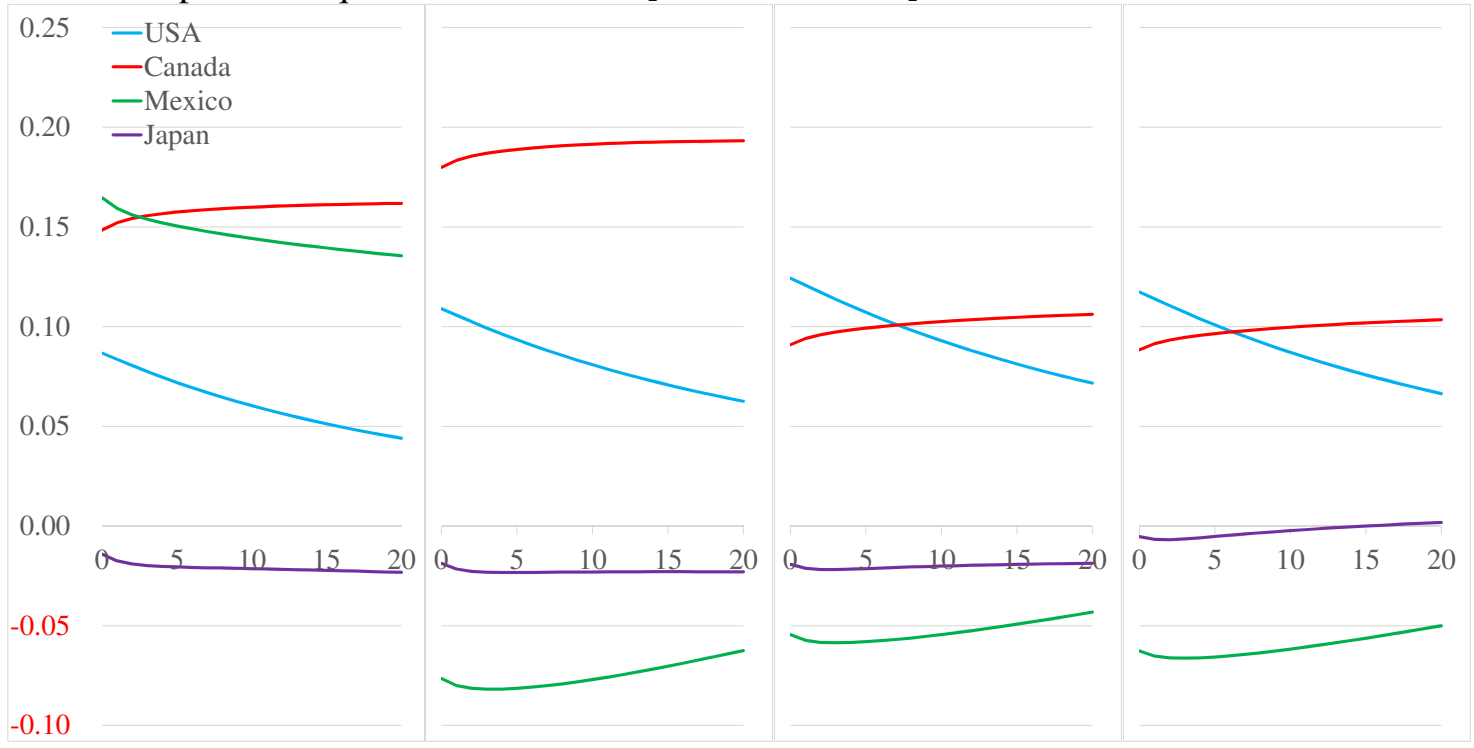


Figure A.3: $1 \%$ Point Larger Depreciation Rate $(\delta)$

Production of Transport Equipment [Deviations from the BAU Path, billion USD]

Scenario1

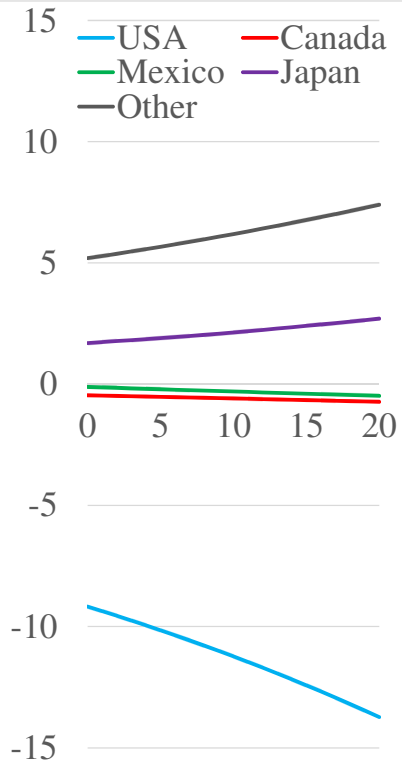

Scenario2

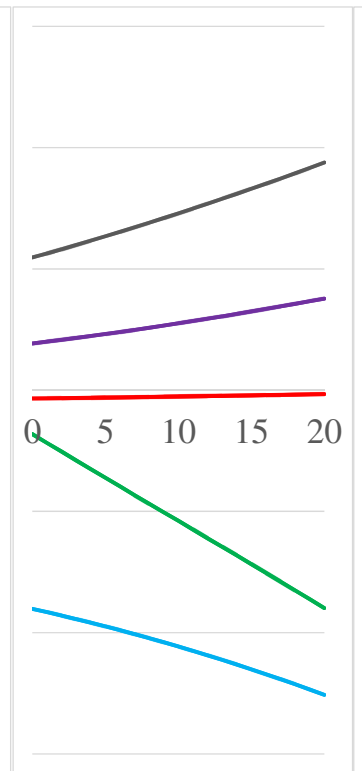

Scenario3

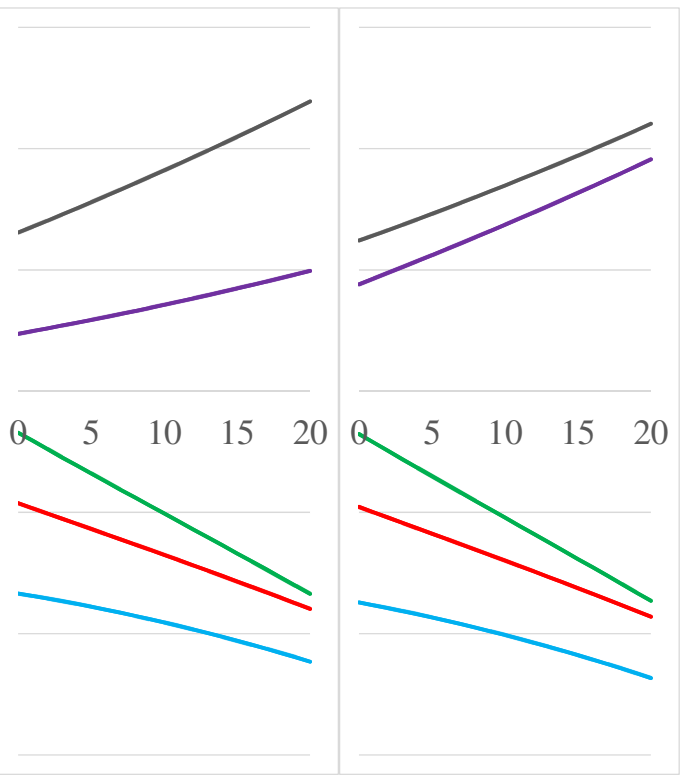

Bilateral Trade [Deviations from the BAU path, billion USD]

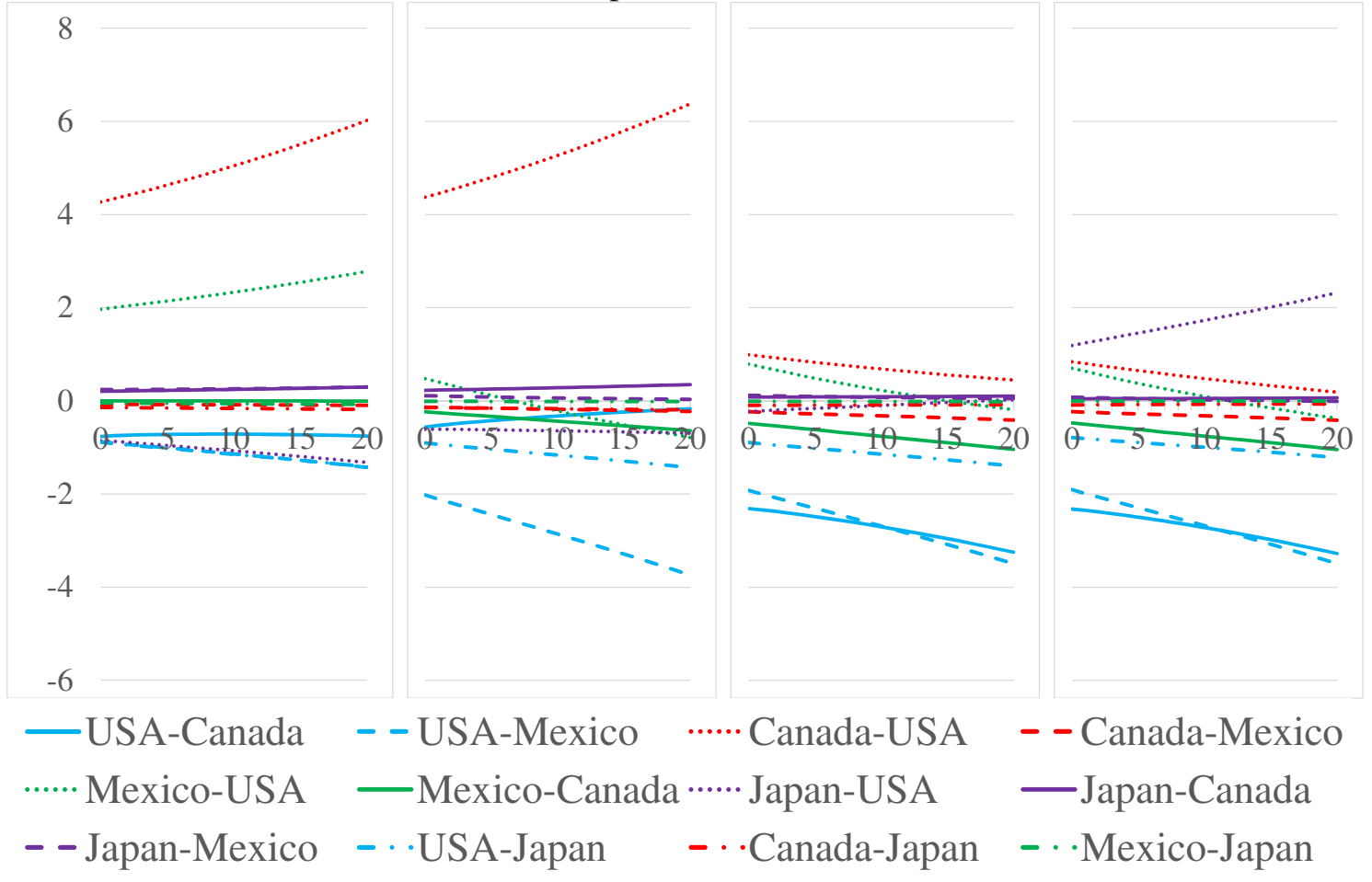


Japanese FDI in the Transport Equipment Sector [Deviations from the BAU path, billion USD]
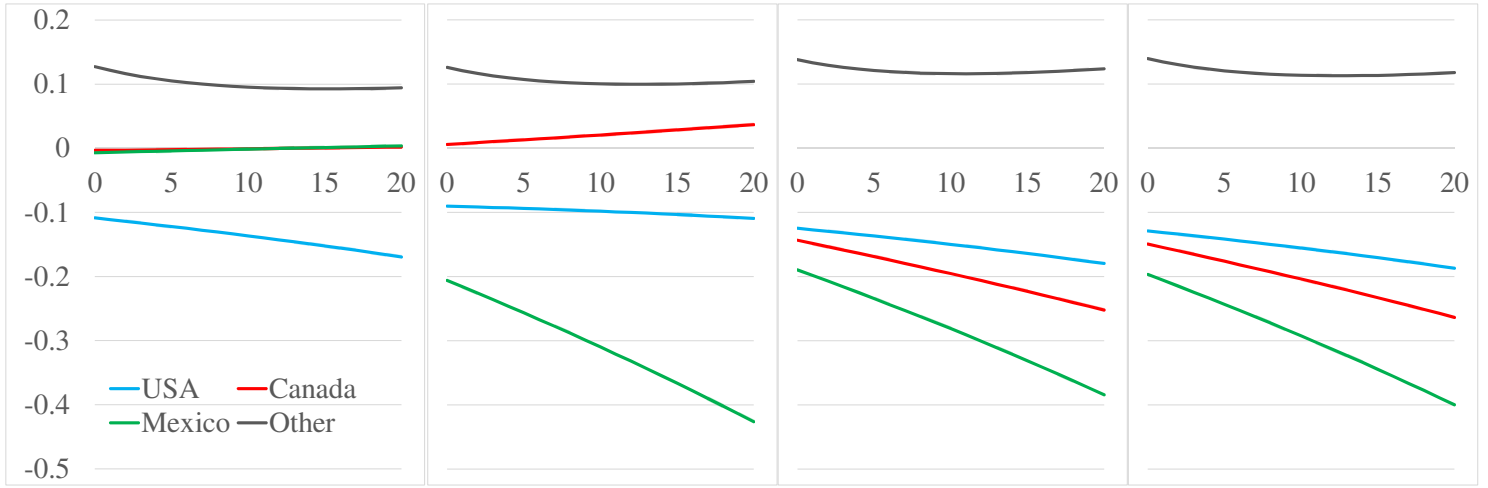

Welfare Impacts in Equivalent Variations [\% of BAU GDP]

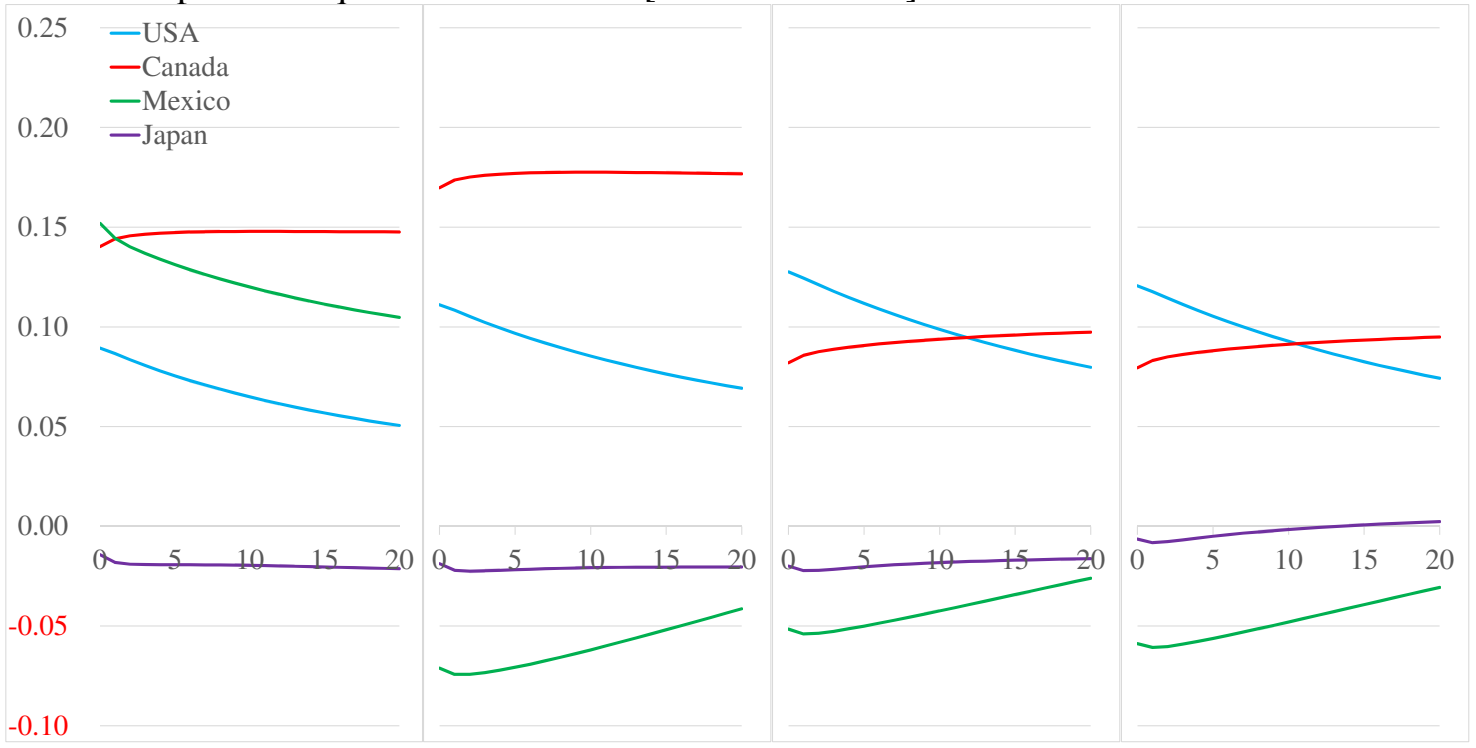


Figure A.4: 1\% Point Larger Rate of Returns (ror)

Production of Transport Equipment [Deviations from the BAU Path, billion USD]

Scenario1

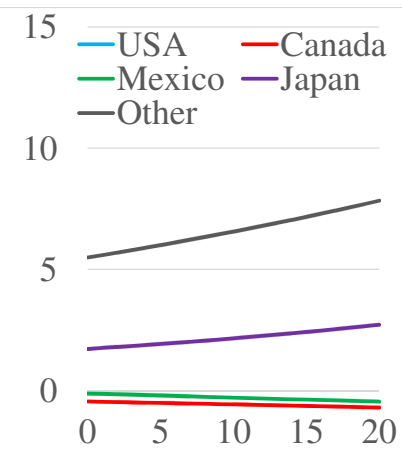

Scenario2

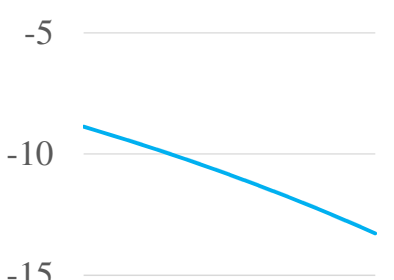

$-15$

Bilateral Trade [Deviations from the BAU path, billion USD]

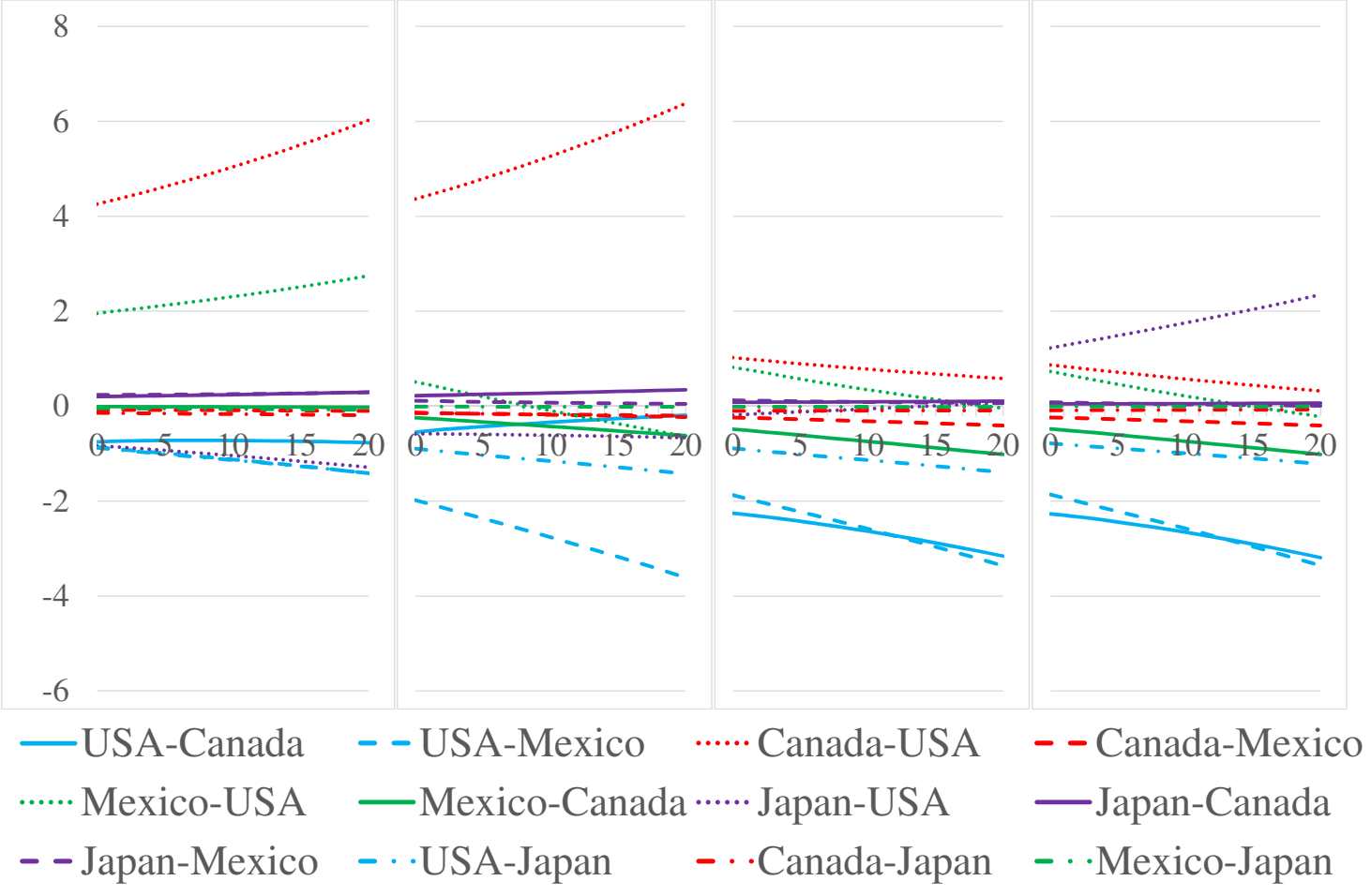

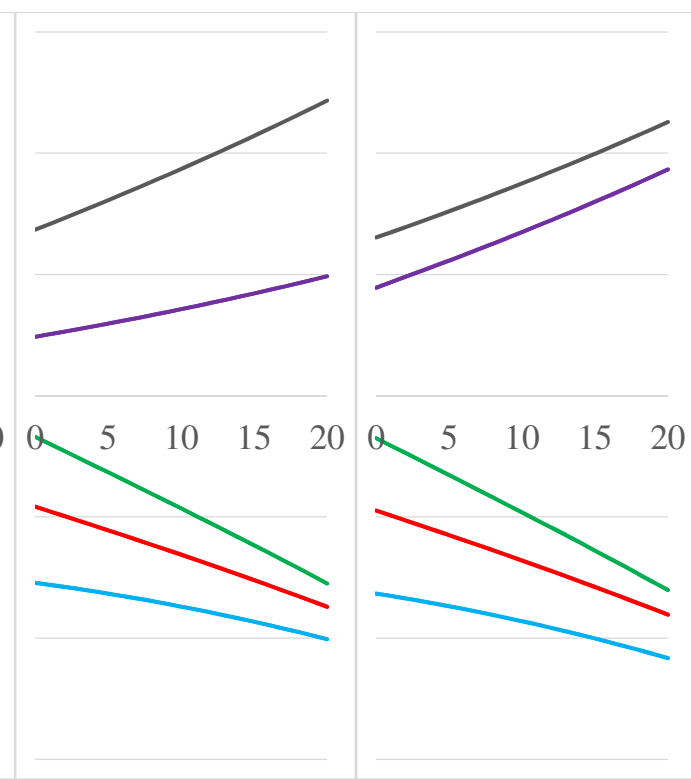

Scenario3 Scenario4 
Japanese FDI in the Transport Equipment Sector [Deviations from the BAU path, billion USD]

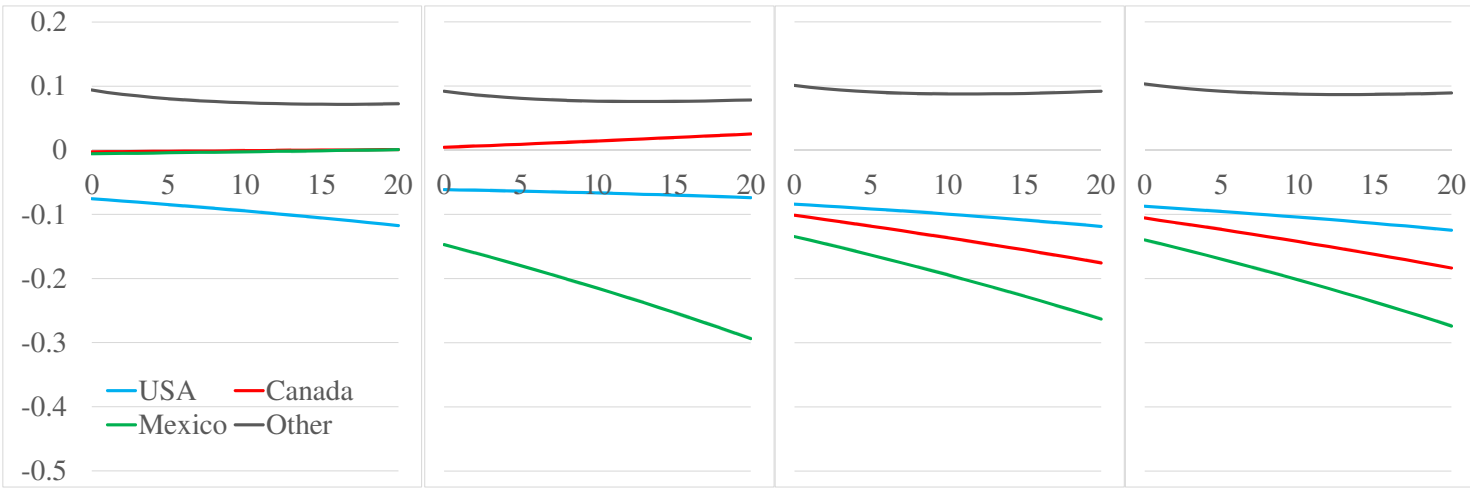

Welfare Impacts in Equivalent Variations [\% of BAU GDP]

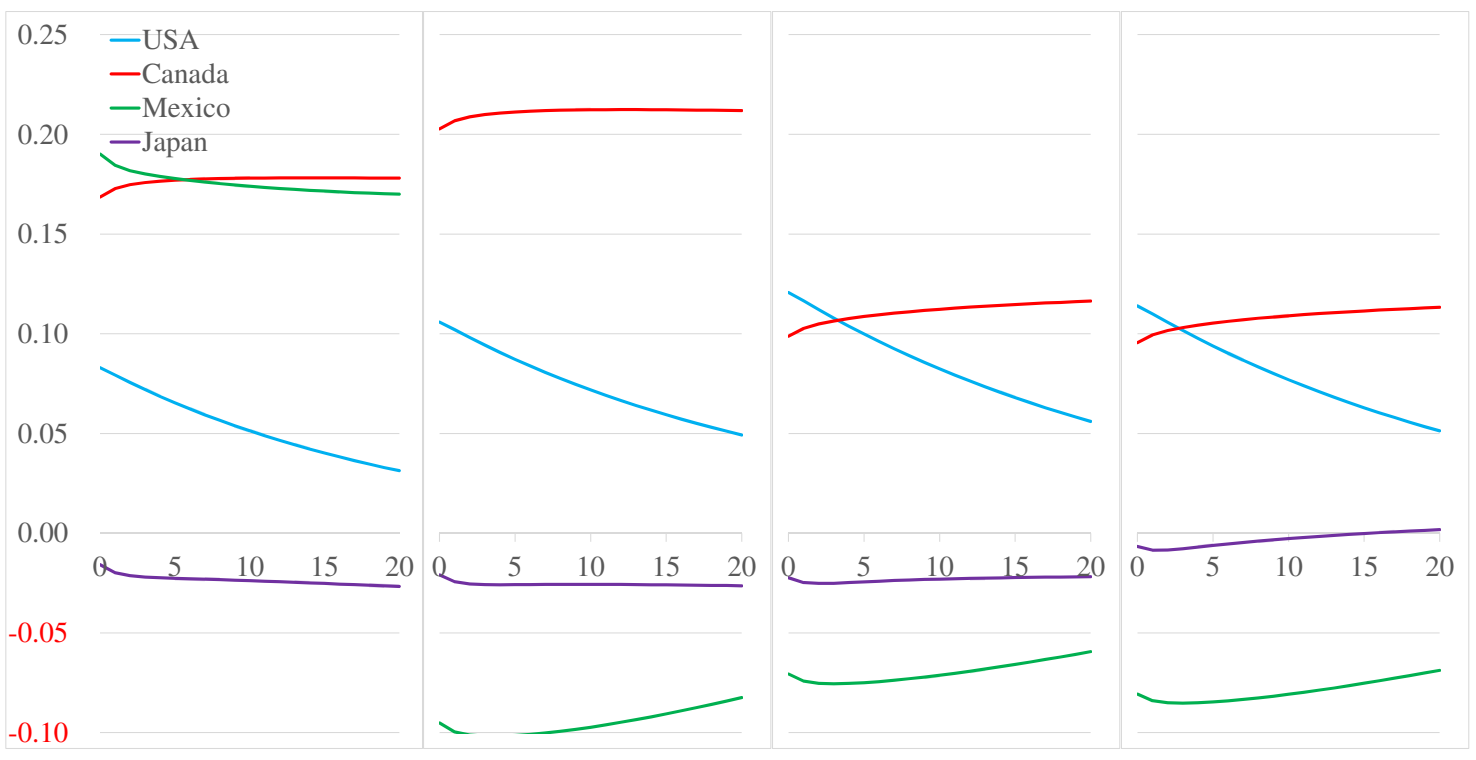


Figure A.5: 1\% Point Larger Population Growth Rate (pop)

Production of Transport Equipment [Deviations from the BAU Path, billion USD]

Scenario1

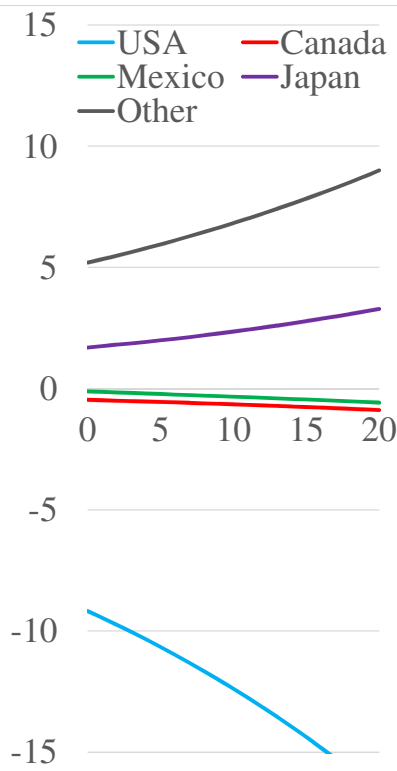

Scenario2

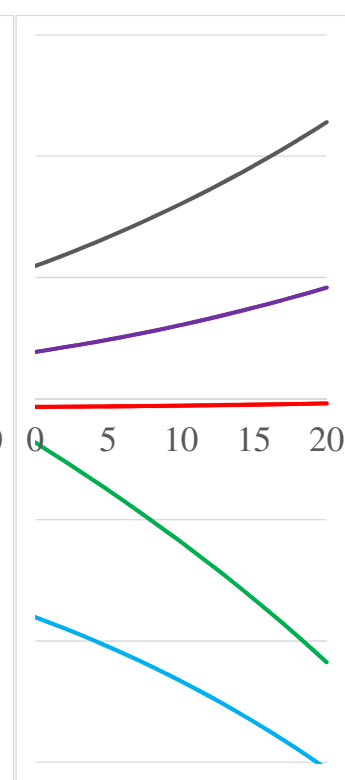

Scenario3

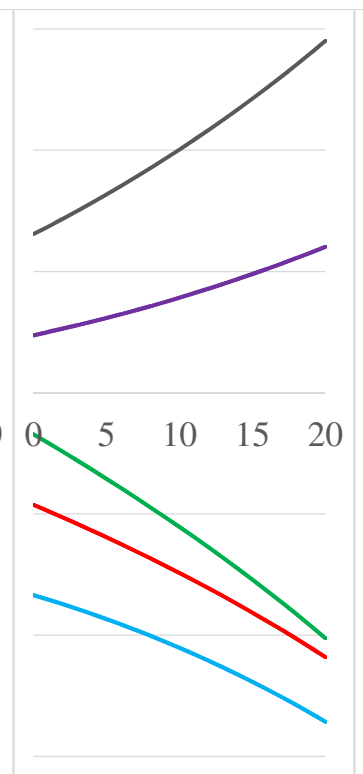

Scenario4

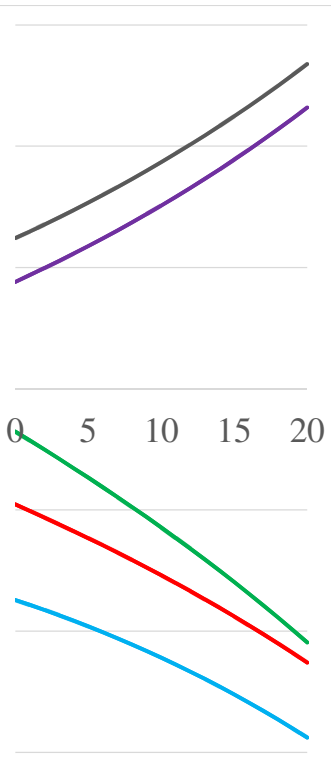

Bilateral Trade [Deviations from the BAU path, billion USD]

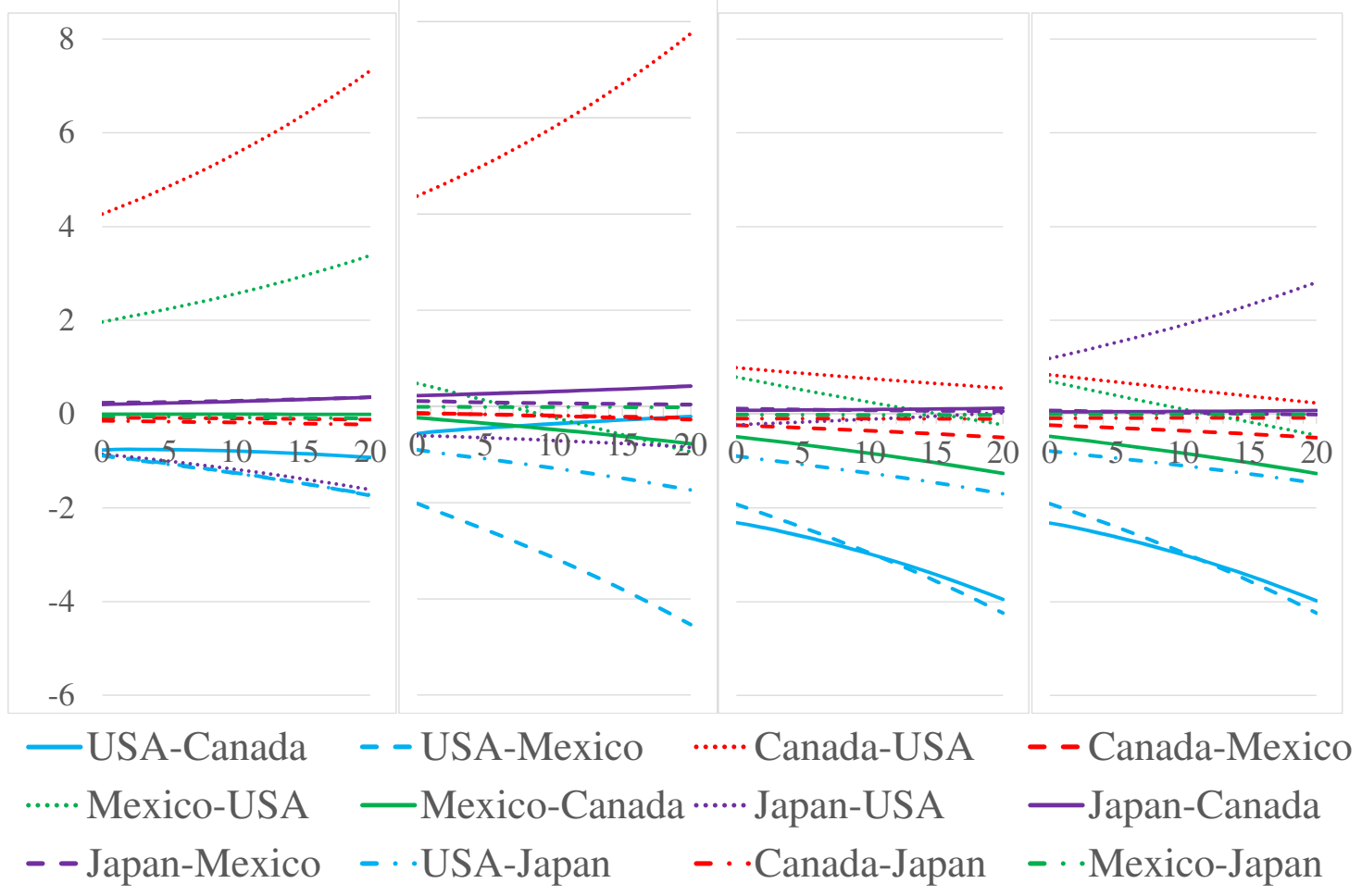


Japanese FDI in the Transport Equipment Sector [Deviations from the BAU path, billion USD]

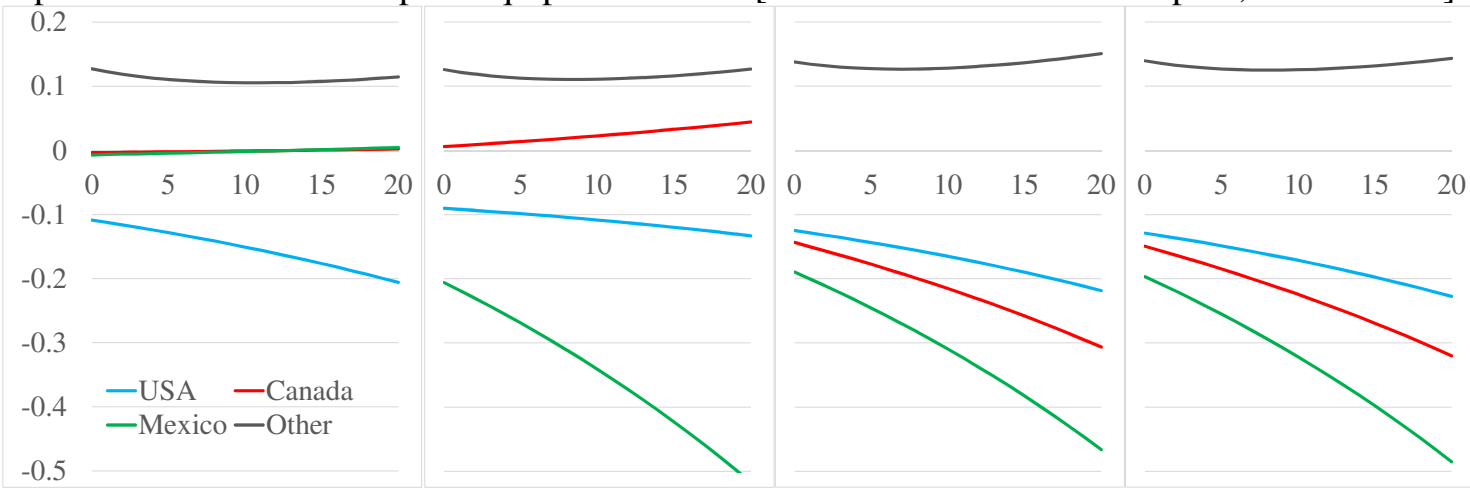

Welfare Impacts in Equivalent Variations [\% of BAU GDP]

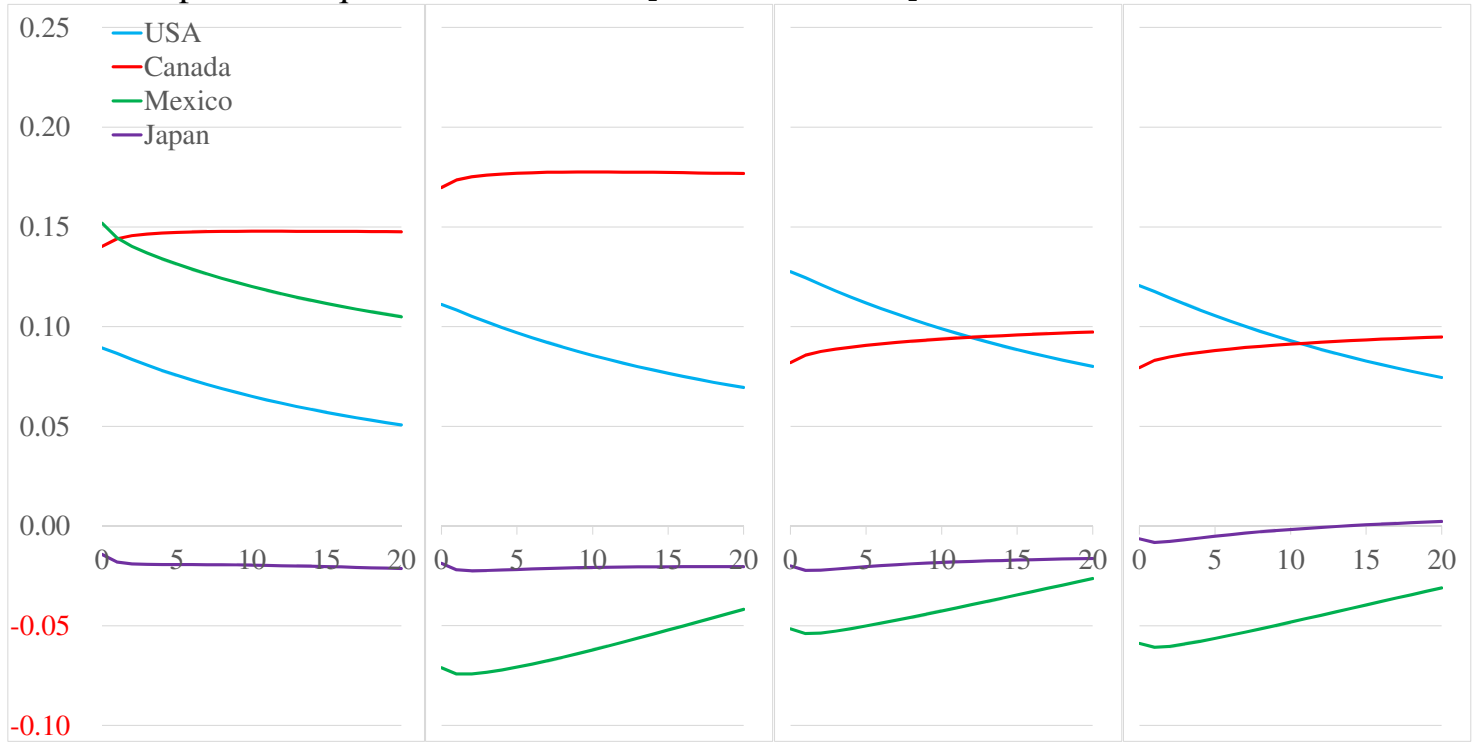


Figure A.6: Larger Elasticity Parameter for Sectoral Investment Allocation Function $(\zeta=2)$ Production of Transport Equipment [Deviations from the BAU Path, billion USD]

Scenario1

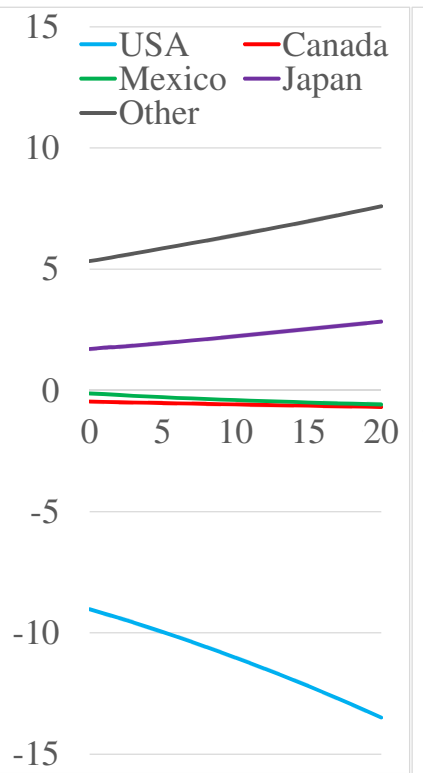

Scenario2

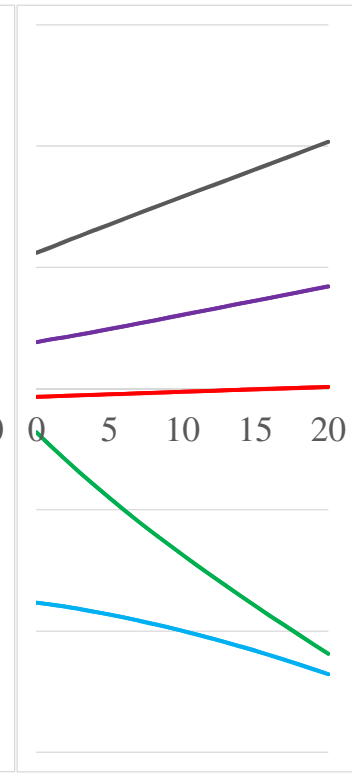

Scenario3

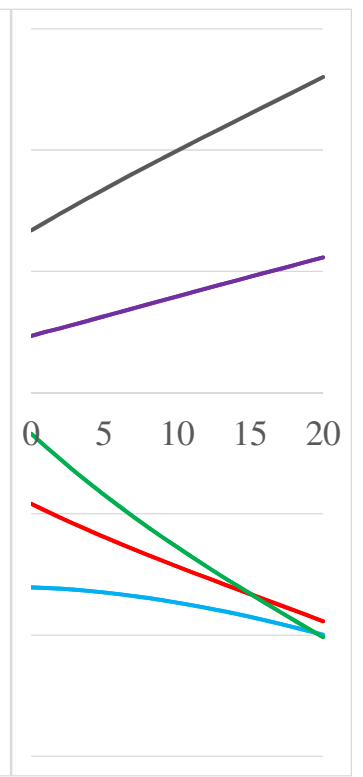

Scenario4

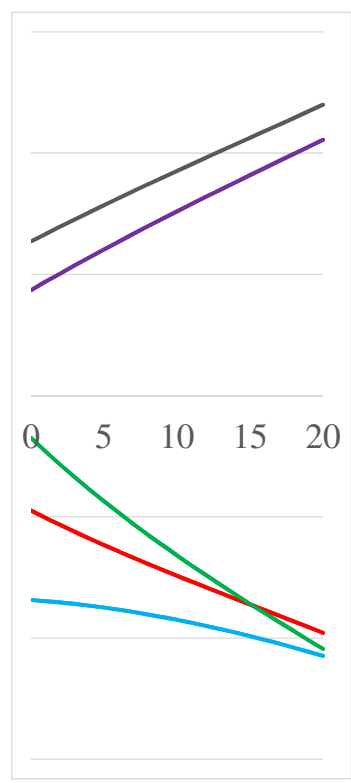

Bilateral Trade [Deviations from the BAU path, billion USD]

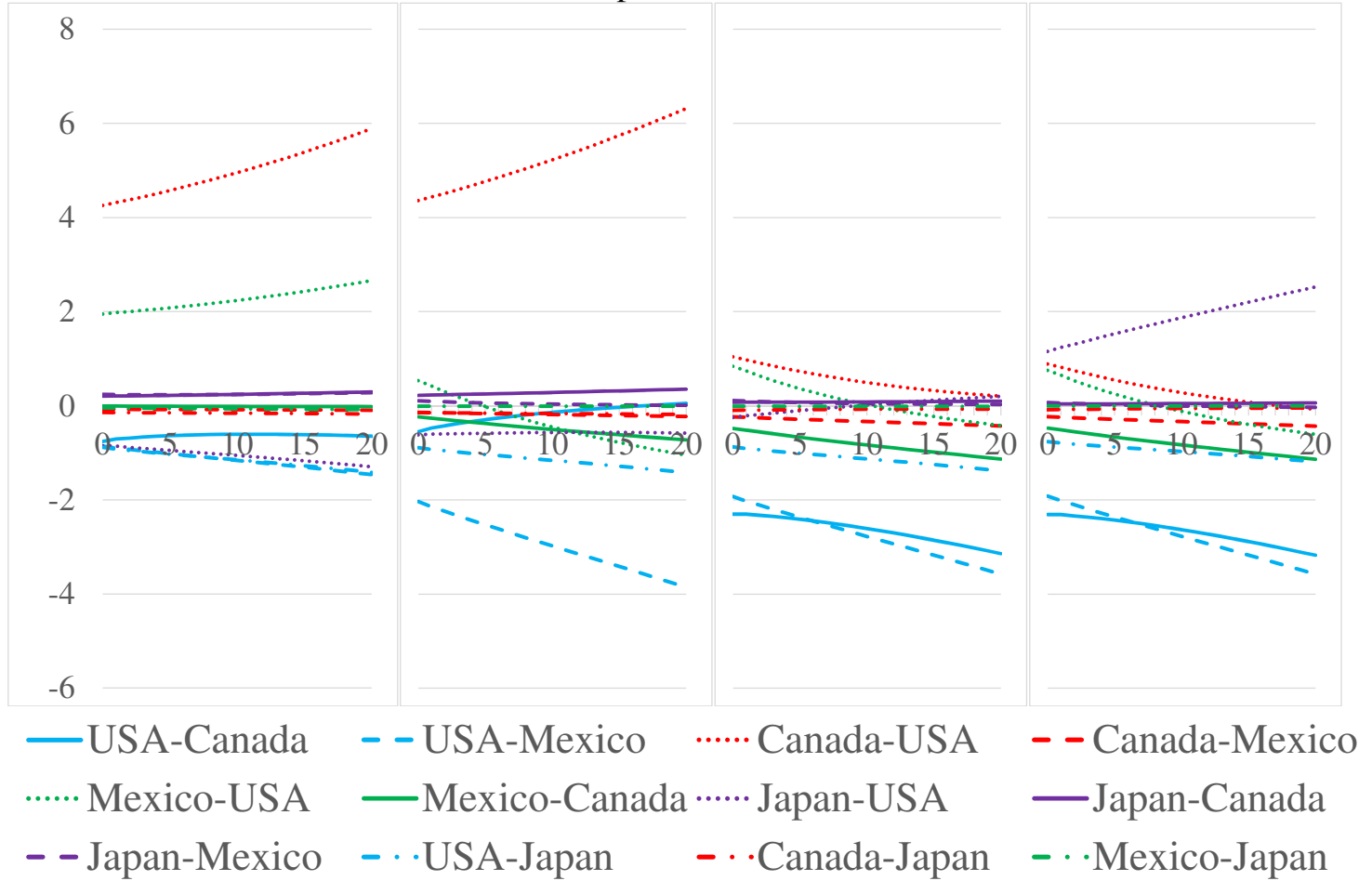


Japanese FDI in the Transport Equipment Sector [Deviations from the BAU path, billion USD]
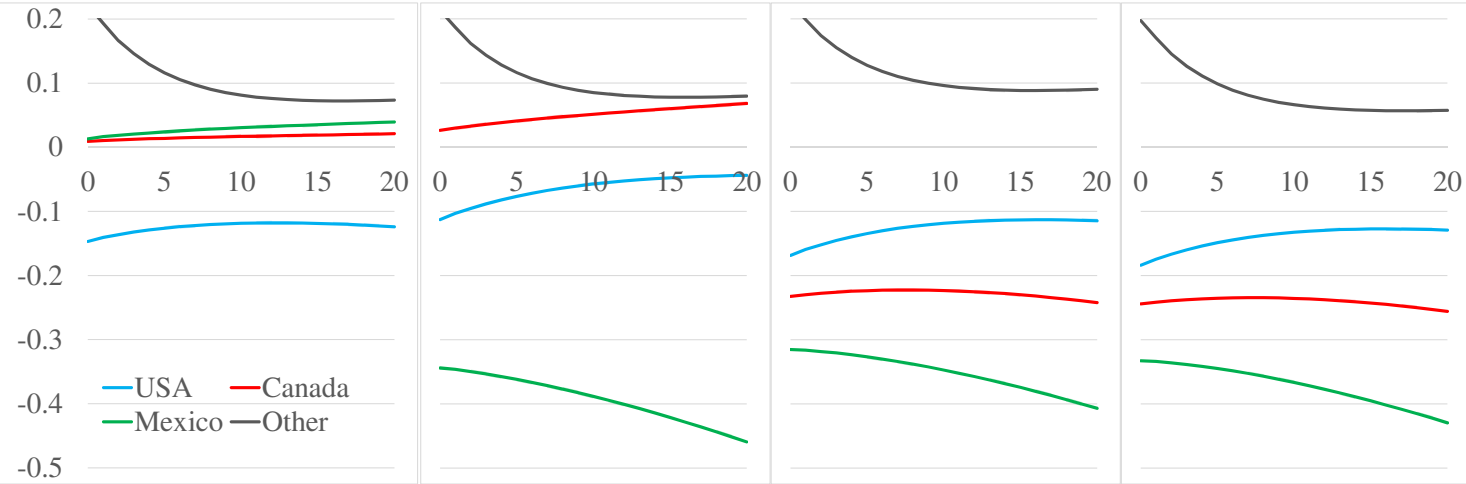

Welfare Impacts in Equivalent Variations [\% of BAU GDP]

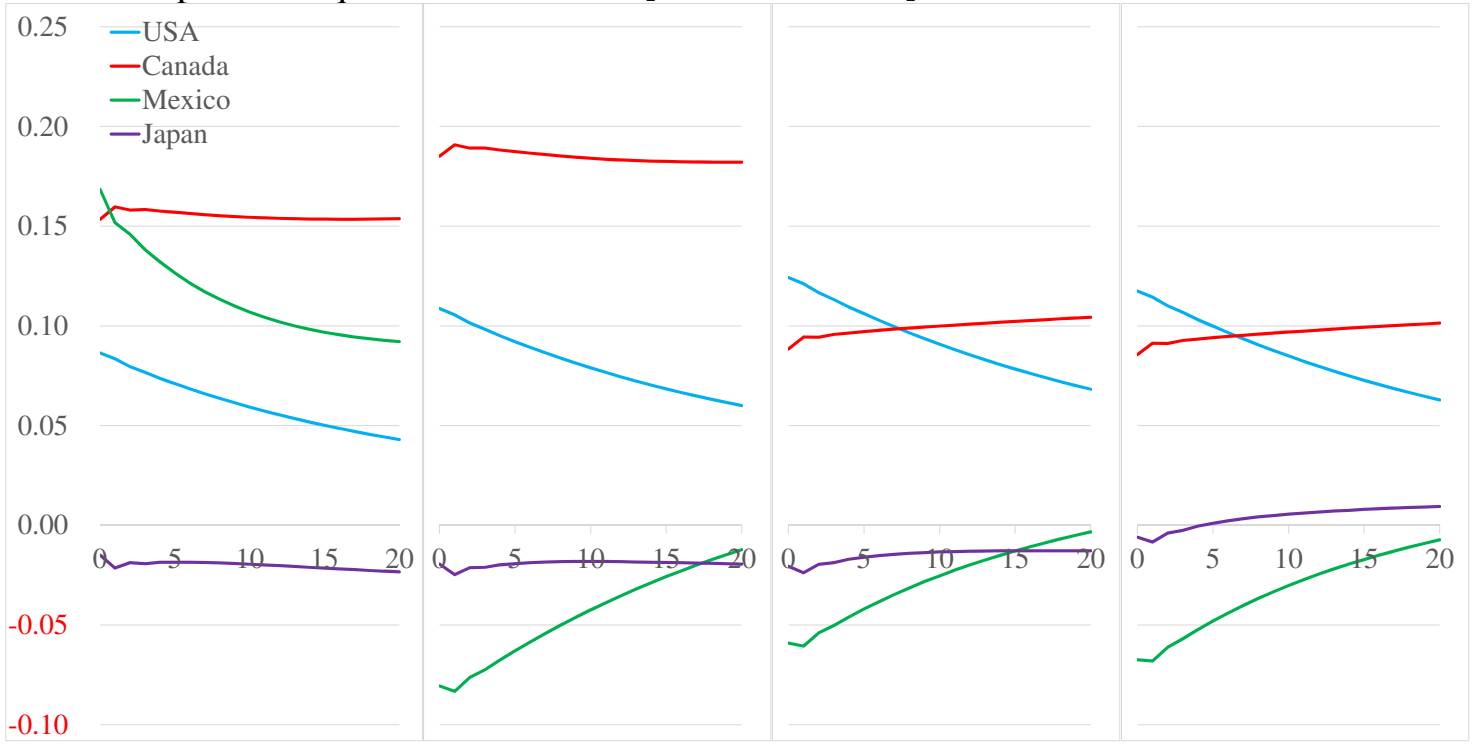

